\title{
REPRESENTAÇÕES DE BRASILIDADE NOS DESENHOS E DISCURSO DE CRIANÇAS BILÍNGUES (PORTUGUÊS/ALEMÃO): UM CONVENIENTE CASAMENTO METODOLÓGICO
}

\author{
Brazilianess Representations In Drawings And Speech Of Bilingual \\ Children (Portuguese-German) - A Convenient Methodological Marriage.
}

\author{
Juliane COSTA WÄTZOLD \\ Fakultät für Erziehungswissenschaft - Universität Hamburg \\ costawaetzold@gmail.com \\ https://orcid.org/0000-0002-6663-6162
}

RESUMO: Para famílias que vivem em contexto migratório, a educação bilíngue, nomeadamente o bilinguismo de herança, é uma questão relevante e que, dependendo das políticas linguísticas locais, traz consigo diferentes desafios, demandando planejamento e engajamento familiar. Este estudo apresenta resultados parciais de uma investigação mais alargada sobre a transmissão do Português como Língua de Herança (PLH), num contexto não-formal, na Baviera, Alemanha. Com base em narrativas visuais de crianças bilíngues (idade: 4-14 anos) associadas a análise de conteúdo no âmbito de um focus group com elas, pretende-se conhecer e analisar as suas representações de brasilidade. Foram colhidos 20 desenhos junto aos frequentadores de um projeto socioeducativo para o ensino do PLH, designado "Mala de Herança" (MH). A partir da análise multimodal desses desenhos, a par com a análise das transcrições das entrevistas, pretende-se compreender o que essas representações revelam sobre a relação dos aprendentes com o PLH e como percebem esta língua. Os resultados apontam para a complementaridade das metodologias revelando o potencial heurístico resultante da combinação dos métodos. Conclui-se que esta abordagem metodológica traz vantagens para a pesquisa com crianças plurilíngues, por permitir maior aproximação com o objeto estudado e, abarcando uma dimensão social, por ser uma técnica pouco invasiva. PALAVRAS-CHAVE: Português como Língua de Herança; Brasilidade; Métodos visuais; Análise multimodal.

ABSTRACT: For families living in a migratory context, bilingual education, namely inheritance bilingualism, is a relevant issue which, depending on the local linguistic policy contexts, can lead to challenges, requiring family planning and engagement. The present study presents partial results of a broader investigation on the transmission of Portu- 
guese as a Heritage Language (PHL) in a non-formal context in Bavaria, Germany. Based on visual narratives associated with content analysis within a Focus Group, the study aims at getting to know and presenting the perspective of children (age: 4-14 years) learning this language, portrayed in their representations of Brazilianness. Twenty drawings were collected from those attending a socio-educational project to teach PHL. From the multimodal analysis, it is intended, with the use of associated methodologies, to understand what these representations reveal about the relationship that learners establish with the language and how they perceive its status. The results point to the complementarity of the methodologies and reveal the heuristic potential resulting from the combination of the methods. It is concluded that a combination of the methods offers an effective alternative in the research with plurilingual children, for it allows a greater approach to the studied object, encompassing a social dimension while being a technique that is not very invasive. KEYWORDS: Portuguese as a Heritage Language; Brazilianness; Visual methods; Multimodal analysis.

\section{INTRODUÇÃO}

A presente contribuição tem como objeto de análise a transmissão intergeracional não institucionalizada do Português como Língua de Herança (PLH), aqui entendido como "a língua minoritária à qual os aprendentes são expostos, primeiramente no ambiente familiar, e que convive com a língua majoritária do país de acolhimento" (FANECA; ARAÚJO E SÁ; MELO PFEIFER, 2016, p. 6).

Serão apresentados resultados complementares a um estudo anterior (COSTA WÄTZOLD; MELO-PFEIFER, 2019), buscando ampliar a perspectiva já examinada sobre as representações de "brasilidade" colhidas junto a pais, educadores e crianças bilíngues (português/alemão) que frequentam um projeto socioeducativo para a transmissão do PLH, em Munique, na Alemanha, denominado Mala de Herança (MH)².

\footnotetext{
${ }^{1}$ Brasilidade é a característica ou particularidade do que ou de quem é brasileiro; natureza do que ou daquilo que é brasileiro. Sentimento de simpatia e amor pelo Brasil. https://www.dicio. com.br/brasilidade/ Acesso em 16.10.2020. Veja-se próxima seç̧ão para um entendimento mais teoricamente embasado.

${ }^{2} \mathrm{O}$ presente artigo apresenta os resultados complementares a primeira parte dos dados colhidos junto aos participantes da pesquisa de doutorado e que foi apresentado no DIPROLING 2018. Até a data do DIPROLING havia sido realizada apenas a primeira recolha de dados. Para o estudo atual, as duas etapas que faltavam já haviam sido encerradas, de modo que os dados aqui apresentados representam um recorte parcial do estudo completo. Disponível em: https://congressos.ufmg.br/ index.php/diprolinguas/diproling2018/paper/view/1036. Acesso em 16.10.2020
}

Revista X, v. 16, n. 2, p. 525-567, 2021. 
Para situar o contexto sociolinguístico e político aqui examinado cabe esclarecer que a $\mathrm{MH}$ se caracteriza por ser um dispositivo de ensino não-formal/informal com uma proposta lúdica e sociointeracionista. O projeto consiste em um caso de comunidade de práticas (WENGER, 2010) formado por famílias teuto-lusófonas (em maioria famílias mistas, alemãs e brasileiras) que tem como proposta pedagógica a transmissão do PLH como língua-cultura ${ }^{3}$. Em resumo: a concepção didática da $\mathrm{MH}$ baseia-se na transmissão intergeracional do PLH no ambiente informal (no âmbito do projeto e em casa) a partir das interações familiares, apoiado no livro de literatura infantil como principal instrumento de mediação. Dentro desta proposta, a família assume protagonismo na relação ensino/ aprendizado, visando o uso do PLH como instrumento para construção (e manutenção) de uma identidade etnolinguística (COSTA WÄTZOLD, 2020).

Seguindo a linha de pensamento de teóricos como Hall (1997) ou Castellotti e Moore (2002), para quem as representações são a produção de significado por meio da linguagem e construídas na interação, entende-se que as imagens em torno das línguas, juntamente com motivações e atitudes (NORTON, 2013; PAVLENKO, 2012), constituem o que se convenciona chamar a "dimensão afetiva" do ensino-aprendizagem de línguas (MELO-PFEIFER; ARAÚJO E SÁ, 2017). Assim, pode-se afirmar que as representações das línguas influenciam a paisagem emocional da aprendizagem e, deste modo, a forma como o aprendente se envolve no processo ensino-aprendizagem. Este processo, seja ele relativo ao ensino de língua estrangeira ou de herança, de aprendizado em contextos formais ou não-formais, será sempre permeado pela transmissão de imagens acerca das línguas e das culturas. Destarte, as línguas poderão ser tematizadas como objetos discursivos ou como objetos de apropriação, sendo que essas duas dimensões se corporizam por meio do recurso constante à linguagem e à comunicação, veículos de co-construção e de transmissão de imagens (COSTA WÄTZOLD; MELO-PFEIFER, 2019). Vale dizer, não há processo de ensino-aprendizagem de línguas sem mobilização, construção e reconstrução de representações acerca delas, já que, como postula Galisson (1991) a língua é, ao mesmo tempo, tema da aprendizagem (do que se fala no ambiente de aprendizado), instrumento da aprendizagem (o veículo linguístico por meio do qual ocorrem as interações) e o fim (o objetivo a atingir, sendo este um maior ou menor grau de proficiência). Nesse sentido, já que as representações estão ancoradas na língua (o instrumento de comunicação e interação social), elas servirão para mediar o processo de aprendizagem.

\footnotetext{
${ }^{3}$ Para compreender a concepção e o funcionamento da proposta didático-pedagógica do projeto Mala de Herança ver: COSTA WÄTZOLD, 2020. Sobre língua-cultura ver: Byram e Morgan (1993), Kramsch (1998), Moran e Lu (2001).
} 
No caso apresentado, o tema, instrumento e fim da aprendizagem é o Português, num contexto duplamente particular. Por um lado, aborda-se o estatuto sociolinguístico de língua de herança (LH) e, por outro, um contexto não-formal de ensino-aprendizagem, o projeto MH. Em relação a este estatuto sociolinguístico particular, veremos que o fato de o Português ser uma língua minoritária no contexto de língua majoritária alemã (duas línguas de diferentes famílias linguísticas) e de se analisar as práticas de transmissão intergeracional numa comunidade particular de imigrantes (a comunidade teuto-lusófona em Munique) influenciará o teor semântico das imagens de português e de brasilidade, ressaltando-se uma identificação identitária e cultural com a língua. Em relação ao fato de se tratar da análise de um dispositivo não-formal de ensino, pode-se antecipar - com base no caráter situado das imagens - que essas serão diferentes das imagens mais comuns diagnosticadas em ambientes formais/escolares: nesses contextos, a língua tende a ser vista como objeto escolar e de apropriação (KALAJA; DUFVA; ALANEN, 2008) ao passo que, no caso, em tela ela assume um viés discursivo.

Um outro objetivo deste estudo é demonstrar em que medida o uso de métodos visuais na investigação, nomeadamente na fase da coleta e análise de dados, é adequado para abarcar temas como aproximações e afastamentos em relação a outros métodos, questões éticas e metodológicas, além das vantagens e desvantagens que os métodos podem implicar.

Assim sendo, pretende-se, com esta contribuição, responder às seguintes questões de investigação:

1) Que representações da brasilidade emergem dos desenhos e das entrevistas de crianças bilíngues na Alemanha?

2) Em que medida os dois métodos de diagnóstico de representações (desenhos e entrevistas focus group - FG) se complementam na investigação com crianças bilíngues?

Para responder a essas questões, será apresentado um enquadramento teóricoprático sobre o uso de metodologias visuais com crianças e adolescentes plurilíngues. Com base em análise de conteúdo das discussões realizadas com as crianças frequentadoras do projeto, e em análise multimodal dos desenhos recolhidos junto a elas durante três FG, comparamos as imagens da língua e da brasilidade obtidas, de forma a compreender o que as representações colhidas na $\mathrm{MH}$ nos revelam sobre a relação 
estabelecida pelas crianças com o PLH e este dispositivo didático de intervenção junto das comunidades brasileiras no exterior.

Cabe adiantar que, para o recorte aqui apresentado, recorreu-se a um design metodológico exploratório, ancorado em uma perspectiva de investigação de teor etnográfica, que visa reconstruir a narrativa da investigação mostrando mais a investigação como processo do que como produto. Antes de adentrar a parte empírica deste estudo, faz-se necessário, todavia, definir alguns conceitos guiadores na análise.

\section{ENQUADRAMENTO TEÓRICO-METODOLÓGICO}

\section{Sobre o conceito de Brasilidade}

De antemão, por ser um termo pouco difundido em discursos científicos (ou até por ser potencialmente considerado pouco científico), é preciso tematizar a noção de brasilidade. Como um complexo de significados e representações construídas e reconstruídas pela cultura nacional brasileira, o termo brasilidade é um conceito que tem sido interpretado de diversas maneiras, sob a ótica de reflexão crítica dos cosmopolitas, nacionalistas, românticos, naturalistas, modernistas, de esquerda, de direita, entre outros (SCHWARZ, 1987).

Assim, adotando o exemplo de Hall $(2006,2012)$ sobre a "inglesidade": só se sabe o que significa ser "brasileiro" devido ao modo como a "brasilidade" veio a ser representada. Cabe salientar que estas representações estão em permanente formação no interior da cultura nacional, pois, segundo Hall (2006, p.50) "uma cultura nacional é um discurso - um modo de construir sentidos que influencia e organiza tanto nossas ações quanto a concepção que temos de nós mesmos". Desta forma, entender toda a dinâmica que a constante construção do significado de brasilidade representa é uma tarefa complexa, uma vez que este é um termo polissêmico, conectado em múltiplos agenciamentos de sentidos (VARGAS, 2007).

Em linhas gerais, a brasilidade pode ser entendida como a designação particular que recebe a identidade nacional (COSTA LIMA, 2006, p. 13). Em vez de tratá-la como uma noção assente, incorporada e aceita sem discussões, pretende-se aqui tratá-la como a evidência de uma cultura brasileira que pode aparecer consubstancializada em elementos diversos, em especial aqueles que costumam ser amplamente compartilhados (SIMÃO; MARQUES, 2020). Entre aqueles demasiado conhecidos pelo senso comum figuram, por exemplo, o futebol, a caipirinha, a feijoada, o carnaval, os belos corpos femininos, 
a alegria e a descontração do povo do Brasil, ou seja, elementos convencionalizados e reconhecidos socialmente como pertencentes e capazes de identificar o Brasil e os brasileiros. (RIBEIRO, 2013, p. 362)

É possível verificar especificidades, alguns atributos e categorias simbólicas que compõem o constructo de brasilidade através de diferentes momentos históricos e acontecimentos sociais, bem como através da análise de algumas obras de intelectuais brasileiros ${ }^{4}$ que, na busca por entender e problematizar a brasilidade acabaram por criar discursos que têm povoado a memória coletiva dos brasileiros e hoje podem ser conhecidos e reconhecidos nacional e internacionalmente como imagem de Brasil e dos brasileiros.

Cabe, contudo, pontuar que, dada a abrangência do termo brasilidade, para a presente análise não se buscou operacionalizar os dados obtidos a partir de critérios estanques ou pré-definidos, de modo a realizar uma seleção de características válidas ou não válidas. No caso dos participantes deste estudo, por tratar-se de famílias teuto-brasileiras em contexto migratório, assume-se que as representações trazidas e partilhadas pelos participantes sejam familiares e, ao mesmo tempo, identitárias, no sentido de revelarem atributos e significados relativos à percepção das crianças sobre a identidade brasileira. Buscou-se, assim, a partir do diagnóstico destas imagens de brasilidade, identificar quais relações as crianças estabelecem com o PLH, ou o que as imagens podem revelar sobre a percepção do estatuto desta língua.

\section{A Etnografia como a "cozinha da pesquisa": o caso da pesquisa com crianças bilíngues}

Um outro esclarecimento preliminar que se faz necessário diz respeito à ancoragem metodológica deste estudo. Deve-se destacar que a presente abordagem está situada dentro de um paradigma etnográfico da investigação em educação, em que a própria busca do caminho e do 'saber fazer científico' já são partes da pesquisa (DE ANDRE, 2016). Na linha deste paradigma pós-positivista, pretende-se aqui reconstruir a narrativa da investigação, tornando claros os desafios enfrentados e, assim, contribuir para uma reconstrução transparente da temporalidade e do nexus da investigação etnográfica. Assim sendo, este estudo mostrará os bastidores da investigação, no sentido proposto

\footnotetext{
${ }^{4}$ Ver: Freyre (1947), DaMatta (2001), Holanda (1993), Ribeiro (2006). Vale destacar aqui a visão de DaMatta para quem "o Brasil é país, cultura, local geográfico, fronteira e território reconhecidos internacionalmente, e, também casa, pedaço de chão calçado com o calor de nossos corpos, lar, memória e consciência de um lugar com o qual se tem uma ligação especial, única, totalmente sagrada", DaMatta (2001, p.11-12).
} 
por Bourdieu (1977) $)^{5}$, de mostrar a investigação como processo, não se limitando apenas a mostrar os resultados da investigação feita, vale dizer, a investigação como produto. Neste sentido, na linha da investigação de natureza etnográfica, mostra-se a lógica que foi guiando as diferentes fases da investigação que se ia fazendo e construindo, num percurso reflexivo que diz tanto do investigador (a autora desta contribuição), como do objeto de estudo ou das próprias dinâmicas do campo em que os dados foram recolhidos.

Do mesmo modo, vale salientar que a pesquisa com crianças implica uma certa flexibilidade para a interação visando o êxito da incursão ao campo, o que não equivale a executar a investigação com menor rigor metodológico. Pelo fato de a investigação com crianças multilíngues estar ainda pouco desenvolvida, especialmente com enfoque nos contextos não-formais de aprendizado de LH, propôs-se aqui um design original, que intitulamos 'casamento de conveniência metodológico', uma vez que partiu da produção de desenhos pelas crianças para, posteriormente, as engajar em interações no FG que desocultassem ou complementassem os sentidos construídos com recursos a métodos visuais. Considerando que um método nunca oferece as mesmas possibilidades que o outro, como será demonstrado, buscou-se com esta estratégia, tirar o maior proveito heurístico da confluência dos dois métodos. Tendo em conta que este estudo se dedica ao diagnóstico de representações de brasilidade, um tema potencialmente afetivo, o recurso a estas metodologias justifica-se pelo fato de que "literal language, which is discursive rather than nondiscursive, is not particularly helpful when it comes to matters of feeling and their representation" (BARONO \& EISNER, 2012: 9). Por outro lado, conforme refere Melo-Pfeifer (2020), o uso de desenhos, (que no nosso estudo complementamos com a sua discussão em FG), favorece

“outros modos de expressão, beneficiando a participação de públicos na investigação que, por diferentes motivos, podem ter dificuldades na expressão verbal (problemas de audição ou de fala, imigrantes recentes e refugiados, ...), oferecendo uma "voz multimodal" a "voice-deprived audiences", desse modo promovendo maior equidade na produção de factos e discursos científicos" (MELO-PFEIFER, 2020).

Consideramos que a investigação com crianças se situa potencialmente neste grupo.

\footnotetext{
${ }^{5}$ Ver: Pierre Bourdieu e a produção social da cultura, do conhecimento e da informação (Orgs.) Regina Maria Marteleto e Ricardo Medeiros Pimenta. - 01. ed. - Rio de Janeiro: Garamond, 2017. 


\section{PRESSUPOSTOS DA INVESTIGAÇÃO ETNOGRÁFICA REALIZADA - ACERCA DA SELEÇÃO DOS INSTRUMENTOS DE GERAÇÃO DE DADOS}

Como mencionado na introdução, o estudo atual reporta os resultados parciais obtidos durante a recolha dos dados para uma investigação maior que, além da perspectiva das crianças, buscou compreender a percepção dos pais sobre a transmissão intergeracional do PLH no contexto não-formal de aprendizado. Assim, junto aos pais, os dados foram colhidos por meio de entrevistas semiestruturadas, que, todavia, não serão aqui apresentados, já que se pretende enfocar apenas a perspectiva das crianças.

Antes de passarmos para o estudo empírico faz-se necessário ainda situar os métodos de recolha e de análise dos dados empregados.

\section{O uso do Focus Group na pesquisa com crianças}

Para investigar a perspectiva das crianças, era necessário adotar uma metodologia de coleta de dados menos invasiva, considerando-se não apenas as questões éticas envolvidas na pesquisa com este público (GREIG; TAYLOR; MACKAY, 2013), como também a faixa etária e a capacidade para serem informantes. Ao realizar pesquisa com crianças, é essencial encontrar a melhor ferramenta para encorajá-las a expressar ideias, sentimentos e percepções (CASTELLOTTI; COSTE; MOORE, 2001). Optou-se, assim, pela realização da técnica do FG, apoiada no uso de narrativas visuais.

Segundo Ibrahim (2019), o desenho permite a construção de símbolos e conceitos visuais, vistos e interpretados por um certo período, em um determinado grupo. Para as crianças, oferece, ademais, recursos que permitem uma expansão das possibilidades de expressão e narração, facilitando recriar e reinventar essas vidas altamente complexas e diversas. Além de os desenhos servirem, também, para elucidar os dados no nível linguístico-verbal, são considerados uma ponte entre o meio semiótico da imagem para a fala, como um meio alternativo de representação e comunicação de conhecimento e entendimento (HOPPERSTAD, 2010) uma vez que o ato de desenhar requer um alto engajamento pessoal e uma distância reflexiva para apresentar e interpretar os desenhos dentro de um grupo (MOLINIÉ, 2019).

Desta feita, considerando que a construção de sentido acontece em vários `modos', a coleta de dados precisava incluir mais de um modo ${ }^{6}$. A fim de tornar a técnica interessante para as crianças, a partir das orientações da pesquisadora, por facilitar a interação, optou-

\footnotetext{
${ }^{6}$ Poderia ter-se optado por colagens ou fotografias. Considerando-se o tempo disponível para a coleta e a discussão durante o FG, o desenho pareceu ser a opção mais prática.

Revista X, v. 16, n. 2, p. 525-567, 2021. 
se por usar os desenhos (que deveriam ser por elas produzidos) como estímulo para a discussão (CASTELLOTTI et al, 2001), a respeito dos quais fariam suas explanações. Essa escolha deveu-se à necessidade de tornar a atividade também divertida para as crianças, por ser orientada para o social, já que prioriza a interação entre os participantes (GREIG; TAYLOR; MACKAY, 2013). Ademais, o desenho é uma ferramenta com a qual as crianças já estão familiarizadas.

Sobre o FG vale destacar as vantagens desta técnica. Berger (1995) define o FG como sendo grupos de investigação que intencionam descobrir como as pessoas pensam e agem. Eles constituem um tipo de entrevista profunda coletiva, e têm como propósito descobrir o que cada membro do grupo pensa sobre o tópico em discussão. Patton (1990) pondera que o FG é uma técnica qualitativa altamente eficiente que fornece alguns controles de qualidade sobre a coleta de dados, visto que os participantes tendem a controlar e compensar um ao outro, permitindo avaliar até que ponto existe uma opinião compartilhada relativamente consciente entre os participantes. Para Morgan (1988), a finalidade do FG é chegar o mais próximo às compreensões que os participantes possuem do tópico de interesse do pesquisador. Guareschi (1996) pontua que os FG se fundamentam na interação, produzindo dados e insights difíceis de se conseguir fora da interação processada dentro de um grupo, privilegiando uma dimensão social, em vez de uma dimensão individual.

A depender do público envolvido na pesquisa, a entrevista individual não proporcionaria a mesma dinâmica de co-construção de sentido que um FG. Por serem interativos, os FG criam a possibilidade para respostas espontâneas e, como postulam Bokhorst e Marshall (2019), possibilitam a construção de sentido por meio do diálogo, especialmente, se considerarmos a significação das crianças com relação a suas identidades linguísticas. Pode-se, ainda, destacar o fato de ser essa técnica aplicável a grupos pequenos, que compartilham alguns traços comuns, permitindo a identificação e o levantamento de opiniões que refletem o grupo, em um tempo relativamente curto, com a vantagem de reunir muitos participantes em poucos encontros, aspecto relevante no contexto da presente investigação ${ }^{7}$. A técnica permite, assim, conhecer percepções, expectativas, representações sociais e conceitos presentes no grupo (HASSEN, 2002).

$\mathrm{Na}$ área de pesquisa em educação linguística, já se reconhece a necessidade de expandir formatos para a coleta de dados, especialmente no caso de crianças e adolescentes

\footnotetext{
${ }^{7}$ Os contextos não-formais/informais de ensino podem ser especialmente desafiadores nesse sentido. No caso dos participantes da $\mathrm{MH}$, como não há garantia de frequência dos participantes em todos os encontros, realizar um FG possibilitou juntar em menos encontros o maior número de crianças participantes.
} 
(BOKHORST-HENG; MARSHALL, 2019; MELO-PFEIFER, 2015; MELO-PFEIFER, 2017). As narrativas multimodais, com um forte elemento visual, vêm sendo consideradas como um meio de reconhecimento e validação das 'multilingual voices' das crianças (IBRAHIM, 2019; MELO-PFEIFER, 2015). Os dados visuais aprimoram a subjetividade de suas narrativas, que deixam de ser apenas representacionais, passando a ser mais expressivas e interpretativas. Constata-se uma tendência ${ }^{8}$ a reconhecer que a perspectiva multimodal na pesquisa em multilinguismo disponibiliza para os pesquisadores uma poderosa ferramenta para mergulhar nos sentimentos dos participantes, bem como em suas atitudes e percepções sobre o self.

\section{Análise multimodal das narrativas visuais em combinação com análise das discus- sões do Focus Group}

A multimodalidade é conceituada por Kress e van Leeuwen (2001, p. 20) como "the use of several semiotic modes in the design of a semiotic product or event". Por corolário, a análise multimodal compartilha uma perspectiva teórica que entende os recursos semióticos como capazes de influenciar uma comunicação particular e, do mesmo modo, o processo de construção de significado (KRESS, 2000; KRESS; VAN LEEUWEN, 2001; VAN LEEUWEN, 2005).

Incluindo a língua, a análise multimodal examina vários modos dos quais as pessoas se apropriam na comunicação e as formas como esses vários modos semióticos interagem, se reforçam ou se subvertem de forma orquestrada (AHN, 2019). A noção do processo de 'meaning-making' é enfatizada na compreensão da interação dos modos semióticos na medida em que os significados são construídos, distribuídos, recebidos, interpretados e refeitos na interpretação por meio da linguagem - seja como discurso, seja como escrita (JEWITT, 2009).

Nesse sentido, a despeito dos efeitos potenciais dos diferentes modos, o trabalho comunicativo pode ser considerado um processo complexo, sendo que o significado emerge da interação de todos os modos. Assim, como pontua Ahn (2019), pode-se afirmar que a língua é 'um dos meios' pelo qual um indivíduo pode significar o self e os outros na interação social, utilizando a semiótica para conectar o índice linguístico com seu significado social.

Por concordar que se pode enriquecer a análise a partir da multimodalidade é que se optou, no presente estudo, por utilizar as narrativas visuais, na forma dos desenhos

\footnotetext{
${ }^{8}$ Ver: KALAJA, P., \& MELO-PFEIFER, S. (2019). Visualising Multilingual Lives: More than Words. Bristol: Multilingual Matters.
} 
(KALAJA \& MELO-PFEIFER, 2019). Estudos anteriores já mostraram que perguntas de entrevistas verbais e diretas são um ponto delicado, pois podem inibir as crianças. (GREIG; TAYLOR; MACKAY, 2013). Além disso, as narrativas visuais têm demonstrado ser um modo válido e um complexo meio de realizar pesquisa com sujeitos multilíngues em diversos contextos, por permitirem acesso ao imaginário associado com a circunstância de viver entre/com mais de uma língua (MELO-PFEIFER, 2017). As narrativas visuais podem, ademais, ser entendidas como "direct non-verbal discourse", vale dizer que o uso dos desenhos permite ao pesquisador acesso direto à "creative self-expression of the self" (BAGNOLI, 2009). Os desenhos podem, portanto, ser considerados um tipo de dado com uma capacidade heurística completa (MELO-PFEIFER; SCHMIDT, 2019).

Assim, ancorado nesta concepção de análise é que se buscou, com as discussões iniciadas pela investigadora com base nos desenhos produzidos pelas crianças, chegar a um significado co-construído sobre as questões abordadas. Os temas para os desenhos foram pré-definidos para que as crianças tivessem um aspecto comum determinado sobre o qual exporiam suas ideias na discussão. Pretende-se, pois, com esta abordagem, demonstrar como a análise dos desenhos, associada à análise de conteúdo (MAYRING, 2016) das discussões durante os FG realizados, resultou em um método eficaz de engajar as crianças, e, assim, conhecer suas perspectivas.

\section{O ESTUDO EMPÍRICO: UMA RECONSTRUÇÃO DOS CONTEXTOS E PRÁTI- CAS DE INVESTIGAÇÃO}

No caso em tela, a coleta de dados foi realizada em três etapas diferentes, o que decorreu do contexto informal em que o objeto de estudo está inserido. $\mathrm{Na} \mathrm{MH}$, nem sempre as mesmas crianças estão presentes, o que dificulta a organização logística. Assim, da mesma forma como no caso das entrevistas semiestruturadas com os pais, a pesquisadora dependia da aquiescência da coordenadora do projeto em Munique para ter acesso ao campo e aos participantes, bem como de fatores que são importantes na realização de um FG, e podem influenciar no êxito da coleta, como o lugar, a atividade escolhida para o entrosamento do grupo, a disposição do espaço, os materiais utilizados, entre outros pormenores que asseguram a qualidade técnica dos dados. No caso dos desenhos, era sempre necessário que as crianças pudessem usar uma mesa, o que limitava o período de recolha: neste caso, os FG não poderiam ser feitos no verão, quando os encontros da $\mathrm{MH}$ acontecem em espaços abertos ao ar livre, como os parques e jardins da cidade de Munique. $\mathrm{O}$ espaço aberto também pode acarretar problemas para a captação 
do som durante a gravação da discussão em grupo, gerando má qualidade dos áudios, o que dificultaria as transcrições.

Essas constatações foram experiências que a pesquisadora foi acumulando ao longo das tentativas de organização dos FG: buscava-se executar a recolha dos dados da maneira mais ideal possível, visando a melhor qualidade para a fase da apresentação dos dados, e menos dificuldades no momento das transcrições. Pode-se afirmar que as sucessivas coletas não só possibilitaram o aperfeiçoamento na execução da técnica, como ainda viabilizaram obter 'imagens' com contornos mais definidos das representações buscadas.

Os encontros para a coleta de dados ocorreram em 3 etapas diferentes e resultaram no conjunto de perguntas apresentadas na Tabela 1 (ver anexos).

Os FG foram realizados com intervalo de aproximadamente um ano entre cada um. Na ocasião, os pais dos participantes assinaram um termo de livre consentimento esclarecido declarando estarem de acordo com a publicação dos dados (que foram anonimizados) para fins científicos.

No primeiro encontro, em maio de 2018, participaram 9 crianças, no segundo, em fevereiro de 2019 compareceram 5 crianças, e no terceiro encontro, realizado em maio de 2020, 8 crianças estavam presentes ${ }^{9}$. Esse número de crianças por encontro estava sempre dentro do limite ideal, já que, além do tempo para a produção dos desenhos, há de se considerar o tempo de fala de cada criança durante a discussão. As idades variavam entre 4 a 14 anos, como pode ser visto na tabela 2, nos anexos. Neste grupo de 15 crianças bilíngues, apenas 3 são nascidas fora da Alemanha, mas já vivem em Munique há mais de 5 anos. Todas as demais são crianças com background migratório, para as quais o português tem o estatuto de LH e o alemão é a língua dominante. Os codinomes indicados

\footnotetext{
${ }^{9}$ Os dois primeiros encontros foram combinados e organizados com intervenção da moderadora da $\mathrm{MH}$ de Munique, que cedeu tempo do encontro mensal e contactou os pais anteriormente informando que, na ocasião, os dados para a pesquisa seriam recolhidos. No terceiro encontro, a pesquisadora já conhecia os pais, e os contactou por conta própria. Este encontro teve que ser realizado pela plataforma Zoom, já que a recolha de dados foi feita no período do isolamento social, devido à pandemia do novo coronavírus. A princípio pretendia-se fazer a recolha de dados em um encontro mensal da $\mathrm{MH}$, todavia, como não havia perspectiva de data para o fim do lockdown, e como a necessidade de completar a fase da recolha de dados era premente, não restou alternativa senão realizar a coleta virtualmente através de uma plataforma que permitisse compartilhar a tela. Talvez devido ao fato de crianças já estarem habituadas ao uso de ferramentas digitais para a comunicação com a família, e atualmente na escola, não representou nenhum problema para elas participarem do FG dessa forma. Os desenhos foram feitos na semana anterior ao encontro, sob supervisão dos pais que haviam recebido as orientações da pesquisadora de como proceder, a fim também de não interferirem nos resultados e enviados para a pesquisadora. Revista X, v. 16, n. 2, p. 525-567, 2021. 
para facilitar a identificação por ocasião da apresentação dos resultados foram alterados a fim de anonimizar os participantes (ver tabela 2, nos anexos).

No primeiro FG, não havia ainda um entrosamento entre o grupo, já que nem todas as crianças se conheciam da MH. Do mesmo modo, para a pesquisadora, conhecer as crianças ao longo do período de coleta de dados também foi relevante para gerar uma melhor interação e, consequentemente, um bom clima de discussão. Estes são aspectos que podem influenciar o êxito na coleta dos dados (IBRAHIN, 2019). No terceiro encontro, todos já estavam mais familiarizados com as dinâmicas do FG de modo que a atividade transcorreu com mais naturalidade. As discussões eram iniciadas pela pesquisadora com base nos desenhos que serviam como impulso para a discussão em grupo. A língua usada entre a pesquisadora e as crianças em todos os FG foi o português, embora entre elas, enquanto desenhavam, usassem em alguns momentos umas com as outras o alemão e o português para se comunicar.

O tipo (e a quantidade) de perguntas colocadas ao longo das três de coleta se deve ao fato de as crianças serem muito diferentes umas das outras no tocante à capacidade de expressão, o que está relacionado com a heterogeneidade tanto etária quanto à proficiência na língua. Algumas eram eloquentes, já outras eram tímidas, demandando, por isso, mais empenho da pesquisadora para manter o diálogo ${ }^{10}$.

No primeiro FG, a intenção era conhecer representações gerais das crianças acerca do aprendizado do PLH no âmbito da MH, ou seja, no contexto informal. Lápis de cor e um papel do tipo A3 (no qual estava estampado o contorno de uma mala) foram disponibilizados. A orientação dada às crianças para o desenho, na ocasião, foi: "O que é que tem na sua mala de herança? Desenhe como é que você aprende português!". A atividade durou ao todo cerca de duas horas, entre preparação do ambiente, espera pela chegada de todos os participantes, tempo para desenhar, realização da discussão e recolha de todos os desenhos prontos.

No segundo FG, buscava-se aperfeiçoar a orientação com relação à produção dos desenhos e aprimorar a execução da técnica, porquanto, no primeiro, essa parte havia gerado problemas. Gastou-se mais tempo explicando a atividade e produzindo os desenhos do que com a discussão em grupo. Ao realizar as transcrições, constatou-se que a captação do som não tinha boa qualidade em algumas passagens, pois algumas crianças falavam muito baixo.

\footnotetext{
${ }^{10}$ As crianças são honestas e não se envergonham em dizer que não sabem a resposta, ou em alguns momentos, simplesmente demonstram pouco interesse em estender a conversa, o que demanda habilidade de improvisação de quem conduz o FG, no sentido de manter a dinâmica e o ritmo da discussão.
}

Revista X, v. 16, n. 2, p. 525-567, 2021. 
Pretendia-se, portanto, com o segundo encontro, corrigir falhas técnicas na realização do primeiro. Além disso, havia a expectativa de recrutar outras crianças e, assim, aumentar a quantidade de desenhos, além de aprimorar as condições de execução, considerando-se questões como ambiente, qualidade da gravação, e a intervenção da pesquisadora. Do primeiro FG, havia ficado a impressão de que fosse necessário dar mais protagonismo às crianças.

Após reflexão sobre como poderia ser uma orientação que facilitasse a produção dos desenhos e gerasse menos dúvida, no segundo FG, a orientação dada era: "Imagine que você encontrou uma pessoa que nunca esteve em um encontro da Mala de Herança e precisa explicar a ela em um desenho o que é a Mala de Herança! O que você desenharia?”. O segundo FG foi realizado em um ambiente e data diferentes dos encontros da $\mathrm{MH}$, o que favoreceu a atividade, porque as crianças estavam ali apenas para a coleta dos dados.

Após toda uma logística de coordenação da disponibilidade dos pais e das crianças, o encontro ocorreu na sede da Casa do Brasil em Munique, em um domingo à tarde. Na ocasião todos os detalhes técnicos e organizacionais funcionaram, tomando aproximadamente 90 minutos para a realização da coleta. Após dar orientações, a pesquisadora deixou as crianças entre si desenhando, e voltou, após 40 minutos, para a discussão, quando os desenhos já estavam prontos. Do ponto de vista da execução da técnica, os resultados eram satisfatórios.

Dada a abordagem etnográfica, no âmbito do estudo principal (a tese de doutoramento), à medida que se conhecia melhor a perspectiva dos pais, pareceu necessário também conhecer a perspectiva das crianças com relação a pontos que emergiam, como, por exemplo, a questão da identidade linguística. Assim, optou-se pela realização do terceiro FG, no qual a orientação para a produção do desenho foi: "Desenhe o que é ser brasileirinho para você em Munique!".

A coleta de dados junto às crianças em três etapas diferentes resultou, portanto, da assim chamada "lógica em uso" a que se referem alguns teóricos sobre a abordagem etnográfica (GREEN; DIXON; ZAHRLICK, 2005). Vale dizer, fez-se necessário, ao longo da investigação, retornar ao campo para conhecer outros aspectos do objeto estudado.

O último FG, planejado para um encontro presencial, teve, todavia, que ser realizado à distância, devido ao afastamento social imposto pela pandemia do novo Covid-19. Assim, as crianças produziram os desenhos em casa, e houve apenas um encontro para discussão na data marcada, utilizando-se a plataforma zoom. Do ponto de vista da técnica, tudo funcionou a contento, de modo que até mesmo a qualidade estética dos desenhos nessa etapa de recolha foi melhor, provavelmente devido ao fato de as 
crianças não terem sofrido pressão de tempo. As crianças se engajaram e interagiram com naturalidade, a conversa foi gravada e os áudios tinham boa qualidade, de modo que tecnicamente a coleta pôde ser considerada exitosa.

Ao final das três etapas, a quantidade de desenhos juntamente com as falas durante da discussão ${ }^{11}$ (que consistia mais em uma entrevista dialógica) forneciam informação suficiente para se proceder à análise.

\section{APRESENTAÇÃO DOS RESULTADOS}

Para a análise dos dados obtidos, a pesquisadora começou por codificar os desenhos. As imagens foram analisadas de acordo com critérios semióticos como conteúdo retratado, enquadramento, cor, proporções, composição, e textos incluídos nos desenhos (KRESS \& VAN LEEUWEN, 2006). Em um segundo momento, novamente os desenhos foram observados e analisados juntamente com as transcrições das discussões durante o FG. A partir da análise multimodal e de conteúdo, foram obtidas as categorias de representações expostas no quadro 3 (ver anexo).

O quadro 3 (ver anexo) apresenta, em termos comparativos, que categorias e com que frequências emergiram nos desenhos e na discussão interativa. Os campos em branco significam que na respectiva metodologia a representação não aparece. Quanto aos exemplos nos desenhos, os números indicados significam a frequência de ocorrência da imagem.

A seguir, as representações de brasilidade obtidas serão exploradas com mais profundidade. Selecionamos exemplos, para micro-análise, que revelam a forma como, por meio da aproximação e distanciamento entre imagem e fala, os dois métodos se complementam.

\section{Análise comparativa dos desenhos e das entrevistas - apresentação dos resultados e discussão}

Dos 20 desenhos recolhidos, tendo em vista os limites do presente artigo ${ }^{12}$, optou-se por realizar uma seleção daqueles que: i) trouxessem representações evidentes de brasilidade, e, ii) pudessem ilustrar como as duas técnicas se complementam,

\footnotetext{
${ }^{11}$ Foram geradas 3 horas de entrevistas do tipo $F G$ com as crianças.

${ }^{12}$ Cabe mencionar que as etapas de coleta dos desenhos para os respectivos FG se destinaram a responder outras questões especificas do estudo mais alargado e que por não estarem diretamente relacionadas com representações de brasilidade, não foram selecionadas para serem aqui apresentadas.
} 
demonstrando assim, porque seria conveniente realizar um casamento metodológico entre elas, tanto no momento da coleta quanto no momento da análise dos dados.

A partir das narrativas visuais, preliminarmente, pôde-se perceber uma gama variada de representações de brasilidade que emerge dos desenhos. Como foi apresentado no quadro 3 (ver anexo), as imagens produzidas vão desde símbolos nacionais, como a bandeira, que é também a representação mais frequente, a representações linguísticas relativas ao estatuto da língua, o que não emerge dos desenhos, mas do discurso. Começando pelo FG, na apresentação dos resultados obtidos pretende-se articular como as duas metodologias se complementam.

\section{A dinâmica do Focus Group para favorecer a co-construção de sentido}

No desenho 1, abaixo, analisando-se primeiramente apenas as imagens, vê-se que Celina desenhou o cocar de índio, a bandeira do Brasil, um livro e um globo terrestre.

\section{Desenho 1: Celina (9 anos).}

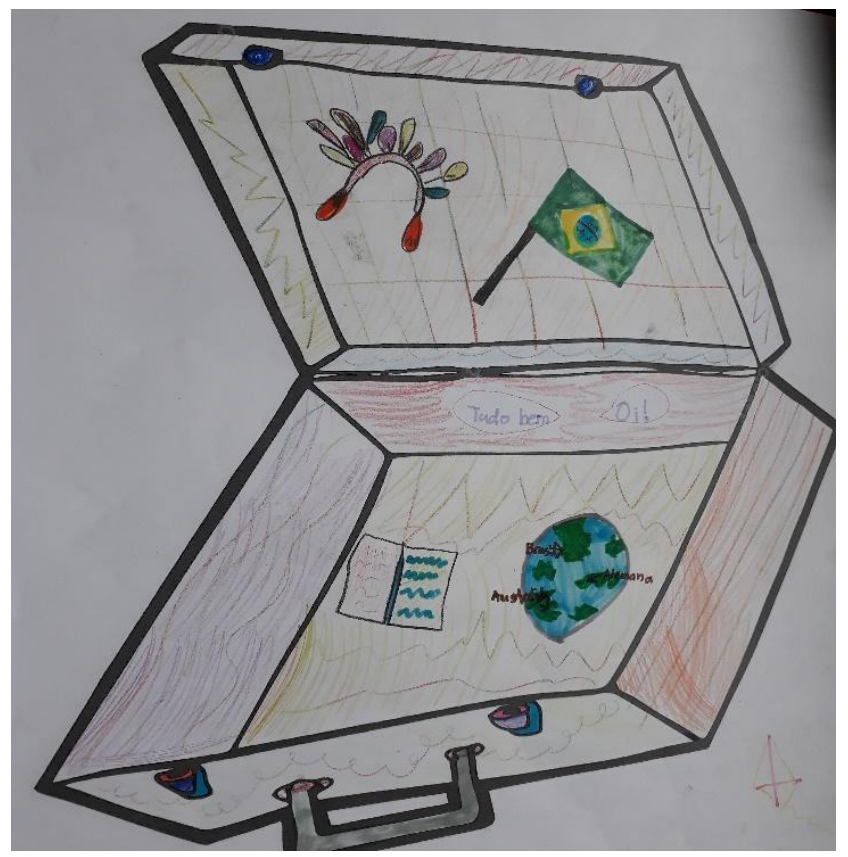

\#PraCegoVer: Desenho em tinta colorido, dentro de uma mala retangular aberta estão quatro desenhos: em uma das partes, acima, um cocar e uma bandeira do Brasil, na outra parte da mala, abaixo: um livro e o planeta Terra.

O desenho corporiza uma representação da brasilidade significativa e ao mesmo tempo óbvia que é a bandeira, ao lado do cocar do índio. Ao explicá-lo, durante a 
discussão em grupo (excerto 1, abaixo), Celina não extrapola o conteúdo representado nas imagens. Todavia, durante a discussão, a explanação de Celina enseja o engajamento de Lina na conversa.

\section{Excerto 1:}

Ce: aqui eu desenhei o mundo, como ali, a gente também tá aprendendo muita coisa como agora, é... como que fala, muito sobre o mundo, por exemplo, aqui, Alemanha, Brasil, Austrália, aqui eu desenhei aquelas... é...

$\mathrm{P}^{13}$ : cocar

Ce: cocar, do índio, porque a gente aprende muito sobre os índios, aqui eu desenhei a bandeira, só para o Brasil, porque (risos) a gente aqui é todo brasileiro, e um livro porque a gente também lê muito... sim.

P: pode falar.

Li: também falar sobre a história do Brasil, assim, sim que era mais ou menos pros índios assim.

No excerto acima, pode-se notar como a dinâmica do FG favorece a interação social e o processo de "meaning making" citado na parte teórico-prática. Como o próprio tempo verbal permite inferir (meaning making), a construção de sentido se dá na interação entre as crianças e a pesquisadora, sendo, portanto, colaborativo por natureza. Nos exemplos que seguem, esta vantagem da dinâmica do FG poderá ser notada.

\section{Narrativas visuais vs. narrativas verbais - nas aproximações e distanciamentos, a complementaridade dos métodos}

Como acima analisado, a imagem desenhada por Celina ensejou o engajamento de Lina, que então complementa a construção do sentido, acrescentando sua percepção sobre o conteúdo aprendido. Celina havia se limitado ao que o desenho representava, ao passo que Lina, a partir da representação, expande o sentido da imagem, referindose ao conteúdo de história do Brasil transmitido, que o desenho representa. Na coconstrução do sentido, evidencia-se a ampliação das possibilidades interpretativas. Com sua intervenção, Lina acrescenta um elemento que o desenho per se não havia fornecido. Esse excerto foi extraído do primeiro FG, em que se buscava obter representações gerais sobre o aprendizado do PLH.

\footnotetext{
${ }^{13}$ A abreviatura $\mathrm{P}$ aparece nas transcrições para identificar as intervenções da pesquisadora. As demais abreviaturas servem para anonimizar os nomes verdadeiros dos participantes.
} 
Abaixo (Desenho 2), o desenho traz um repertório variado de representações de brasilidade. Além de um autorretrato, há um brigadeiro, como representação cultural culinária, seguido da camisa do Flamengo (uma representação do futebol), de um livro, e de uma imagem da vovó.

Desenho 2: Nicole (8 anos).

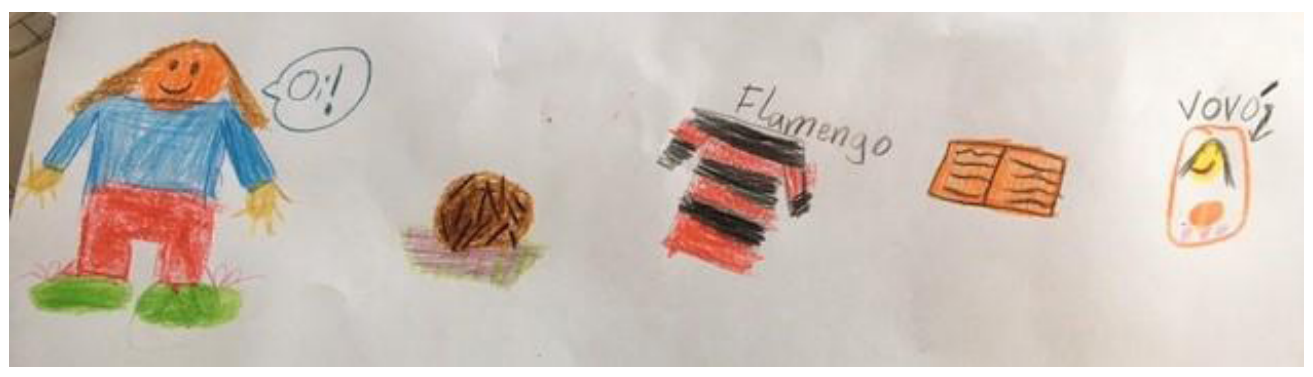

\#PraCegoVer: Desenho colorido. Da esquerda para a direita: uma menina dizendo oi, ela tem cabelos castanhos na altura do ombro, usa blusa azul, calça vermelha e sapatos verdes. Ao lado os elementos: um brigadeiro, uma camisa do Flamengo, um livro aberto, um celular com a imagem de uma mulher na tela e a palavra vovó.

As representações de brasilidade são bastante peculiares e evocam imagens nacionais e locais: o brigadeiro, que é uma verdadeira unanimidade da gastronomia nacional, ou a camisa do flamengo, que remete a uma identidade regional, um ícone da cultura esportiva popular carioca.

Constata-se, em uma primeira análise, a aproximação entre a narrativa visual e a verbal, que coincidem, como se nota no excerto abaixo. Contudo, na evolução da discussão, em sua explanação, Nicole acrescenta informações que a imagem, por si só, não fornece.

Como se nota, sua fala vai além dos elementos representados. A discussão, impulsionada pelas imagens, permite uma ampliação de significados, que leva à compreensão de um outro aspecto relevante, qual seja, o estatuto que a LH tem para ela:

Excerto 2:

P: e o quê que você desenhou aí, Nicole?

$\mathrm{N}$ : é... eu falando português com a mamãe, e com o Nils, e com algumas amigas de mim, é... e aí eu me sinto brasileira, eh... e o outro é que eu tô... um brigadeiro, que a mamãe faz, que é comida do Brasil, é... que é do Brasil... é... e quando... eu me sinto brasileira também quando tem coisas do Brasil. E a blusa do flamengo, que o vovô gosta muito do flamengo, e ele mora no Brasil. E eu também gosto do flamengo. E o Nils também tem a blusa do flamengo. E quando a mamãe lê um livrinho em português, e aí ela fala português com a gente... e eu também 
quando ela lê pra gente... e quando a gente tá falando com a vovó, que ela tá lá no Brasil, aí também fala português.

P: que interessante... então você fala português com o vovô, a vovó, com a mamãe, com o seu irmão, ... e essas coisas te fazem sentir brasileira? $\mathrm{N}$ : sim.

$\mathrm{P}$ : você gosta de falar português?

$\mathrm{N}$ :sim.

P: e é difícil falar português?

$\mathrm{N}$ : não.

$\mathrm{P}$ : e por que não?

$\mathrm{N}$ : porque eu já aprendi desde quando eu era pequena, que a mamãe fala português e ela vem do Brasil.

$\mathrm{P}$ : ah, muito bem.

E você vai na Mala de Herança, Nicole?

$\mathrm{N}$ : sim.

P: e o que é que você acha da Mala de Herança, você gosta?

$\mathrm{N}$ : eu gosto.

P: e por que é que você vai?

$\mathrm{N}$ : porque a mamãe também vai. E eu também gosto, e lá fala também muito português.

P: sim... e você tem amigas lá na Mala de Herança que você fala com elas?

$\mathrm{N}$ : algumas vezes as minhas amigas vêm lá. e aí eu falo.

P: e você acha que a Mala de Herança ajuda a aprender português?

$\mathrm{N}$ : um pouquinho...

A análise multimodal do desenho 2, juntamente com o excerto da discussão, demonstra a vantagem no emprego associado dos dois métodos, evidenciando como a narrativa visual tem grande potencial, não apenas para acessar o imaginário da criança, mas também para impulsionar o diálogo, alargando a discussão.

A conversa iniciada em torno das imagens permitiu que a pesquisadora desdobrasse as percepções compartilhadas pela criança para um outro aspecto relevante, nomeadamente, a dimensão afetiva envolvida no aprendizado da LH. Nota-se que todas as referências por ela apresentadas orbitam em torno da família - o brigadeiro é o doce que a mãe faz, o flamengo é o time do vovô, do qual o irmão menor também tem uma camisa, e o português é a língua que ela precisa saber para falar com a vovó, que está representada no desenho. O português é, em sua perspectiva (de criança bilíngue que cresce em um ambiente majoritário alemão), a língua a ser usada com a família, o que reforça o caráter de family language (CUMMINS, 2014; SCHALLEY, EISENCHLAS, 2020), estatuto pelo qual as LH são conhecidas. Neste caso, a discussão a partir do desenho se estendeu de forma tão exitosa, que revelou a perspectiva da criança sobre o estatuto de língua materna por ela atribuído ao PLH, denotando igualmente sua boa relação com 
esta língua. Foi possível ainda conhecer a forma como ela avalia o modo do aprendizado. Nicole percebe o ambiente da MH como relevante para o desenvolvimento do PLH. O protagonismo materno na transmissão desta língua é por ela destacado, informação que o desenho também não fornecia, revelando assim, a complementaridade dos métodos. Analisado por este prisma, constata-se a diferença de acesso à informação que cada tipo de dado fornece. Evidencia-se, pois, como uma metodologia pode complementar a outra, e como o casamento das metodologias é conveniente.

O desenho 3, abaixo, apresenta também uma gama variada de representações da brasilidade e, na mesma linha de análise, como as metodologias se complementam.

A jaboticaba, nitidamente legendada pela autora, deve ser ressaltada como a mais exótica ${ }^{14}$ das representações, dada a circunstância de ser uma fruta que só existe na América do Sul. Ao lado, aparecem, em uma sequência na parte superior, a bandeira e a praia. Abaixo Felícia intitula a imagem de "A natureza", onde desenhou árvores, notas musicais e um animal quadrúpede. No autorretrato, a criança aparece em proporção destacada, ao centro, com uma expressão alegre. O mais interessante nesta produção multimodal é que, além de trazer sinais de literacia, há uma referência explícita a sua percepção de identidade cultural híbrida, fruto do bilinguismo vivido, como ela explica em sua fala. Em destaque, escreveu: "eu sou metade alemã e metade brasileira".

Desenho 3: Felícia (9 anos).

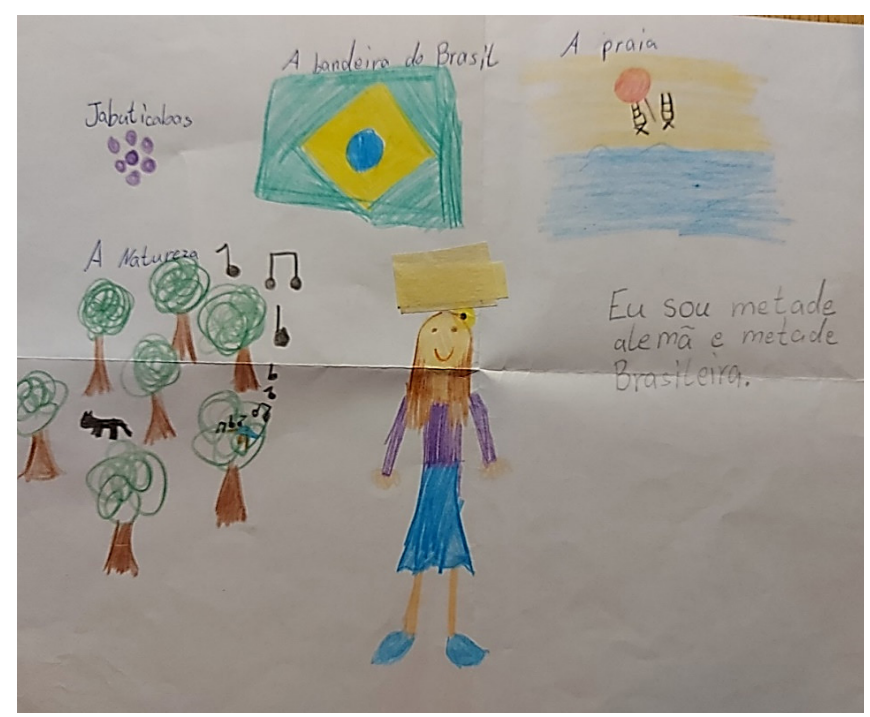

\footnotetext{
${ }^{14}$ A noção de exótico aqui empregada corresponde ao senso comum, como no emprego do dicionário, em que é definida como: "o que não é comum; que expressa extravagância ou excentricidade: animal exótico. Não natural; que não nasceu no país nem na região onde habita; estrangeiro, importado: vegetação exótica." https://www.dicio.com.br/exotico/
} 
\#PraCegoVer: Desenho colorido. No centro uma menina sorrindo, ela tem cabelos castanhos abaixo dos ombros, usa blusa roxa, saia azul e sapato azul. À esquerda, algumas árvores, entre elas um felino preto, em uma das árvores um pássaro e notas musicais, acima está escrito "a natureza". No canto superior esquerdo seis bolinhas roxas e a palavra "jaboticabas". À direita a bandeira do Brasil e ao lado a imagem retrata o mar azul, uma faixa de areia, duas cadeiras e um guarda-sol, acima a palavra "praia". Abaixo a frase "Eu sou metade alemã e metade brasileira".

Este desenho fora produzido para o terceiro FG, como também foi o caso do desenho 2, feito por Nicole. A orientação na ocasião era que desenhassem o que é ser brasileirinho em Munique, de modo que estas representações podem ser entendidas como muito próximas da noção que têm sobre brasilidade. Percebe-se, mais uma vez, a proximidade entre a fala e a imagem, de maneira que as representações se complementam. O sentido torna-se mais compreensível na medida que acrescenta sua visão subjetiva, como pode ser visto no excerto abaixo.

\section{Excerto 3:}

F: eu desenhei jaboticaba, a Amazônia, a praia, a bandeira do Brasil e eu na casa da vovó.

P: você onde?

F: eu na casa da vovó.

P: qual é a parte da casa da vovó? onde tem as árvores?

F: não, eu.

P: ah, esse com uma flor no cabelo, isso?

F: sim.

P: e você escreveu, hein? você já sabe escrever em português! fiquei impressionada... como você já sabe escrever em português. Como você aprendeu a escrever em português?

F: nas aulas de português e com a mamãe.

P: você está escrevendo muito bem! Me explica aqui uma coisa, aqui tem até umas notas musicais... não é?

$\mathrm{F}$ : que é esse passarinho que tá aqui na árvore.

P: ah, ok. A bandeira do Brasil, a praia. E você gosta de falar português, Felícia?

F: sim.

$\mathrm{P}$ : e isso aqui é pra você o que é ser brasileirinha em Munique, né. $\mathrm{O}$ que é ser brasileirinha em Munique, Felícia?

F: falar português em Munique, e alemão também.

P: você é as duas coisas, né, você escreveu aqui. Eu sou metade alemã e metade brasileira.

F: hum hum. (confirmou)

P: com quem que você fala português?

F: eu falo com a família do papai, com a família da mamãe, e com a mamãe e com o papai e com a minha irmã, e com algumas amigas que tem aqui que falam português.

$\mathrm{P}$ : e onde que você encontra essas amigas? 
F: ou na minha casa, ou na casa delas, ou as vezes no parque, que a gente vai lá pra brincar, ou ... sim...

P: você também vai na Mala de herança?

F: sim.

P: você gosta?

F: gosto.

P: o que você mais gosta lá?

$\mathrm{F}$ : quando tem história, e as atividades.

$\mathrm{P}$ : quais atividades?

F: e os teatros, que a Adriana (referindo-se à moderadora) faz com a gente.

P: e você acha que a Mala de Herança ajuda, para falar português?

F: um pouquinho.

P: e por quê?

F: porque eu faço mais coisas com pessoas em português e eu aprendo mais palavras em português.

Como no caso de Nicole, a discussão baseada nas representações contidas no desenho de Felícia ganha um significado mais preciso a partir de sua fala. O conteúdo retratado nas imagens tem proximidade com o conteúdo da conversa. Se tivessem sido analisadas separadamente, as imagens já teriam fornecido pistas de elementos de brasilidade. Contudo, é na fala que sua relação com o PLH fica evidenciada. Constatase, assim, que a associação dos dois métodos alarga a possibilidade de construção do significado, ou mesmo, revela perspectivas que não emergem no desenho.

Este distanciamento se manifesta quando Felícia também expressa em seu discurso percepções relativas ao estatuto do PLH (de língua da família) que o desenho não fornece. A multimodalidade - à qual ela mesma, como autora do desenho, recorre na produção da imagem (na fala e na escrita), é que viabiliza a exteriorização de sua percepção de bilinguismo. A partir da análise de sua fala que fica clara a associação feita entre o bilinguismo e sua identidade híbrida, de criança brasileira que cresce em um contexto migratório. Saliente-se que no desenho ela escreve "eu sou metade alemã e metade brasileira", mas ao explicar o seu desenho ela justifica sua percepção explicando que é pelo fato de falar as duas línguas em Munique. Em seu caso, ambos os pais são brasileiros que vivem em Munique. A colocação de que é metade brasileira e metade alemã revela sua percepção da forma como lida com as línguas de seu repertório e como este fato influencia na construção de sua identidade.

Também neste caso, pode-se concluir que o desenho, além de permitir aceder às representações da criança, tem a vantagem de impulsionar a discussão, alargando o campo para a produção de imagens, no sentido proposto por Hall (1997) e Castellotti e 
Moore (2001), através da linguagem, e na interação, para a construção do sentido. Na investigação mais ampliada, os resultados obtidos a partir das imagens são de grande valia, sobretudo tendo em vista a triangulação com os outros dados gerados. No caso em tela, a questão do bilinguismo, por exemplo, que ela não desenhou, mas escreveu, é um aspecto relevante. Nota-se, ademais, que sua percepção da brasilidade é também um pouco exótica, focada na fauna e flora, ou nas frutas exóticas, como a jaboticaba. A praia remete, também, a uma visão de brasilidade bem próxima do estereótipo e da visão que o 'turista' tem do Brasil ${ }^{15}$.

Desenho 4: Iara (12 anos).

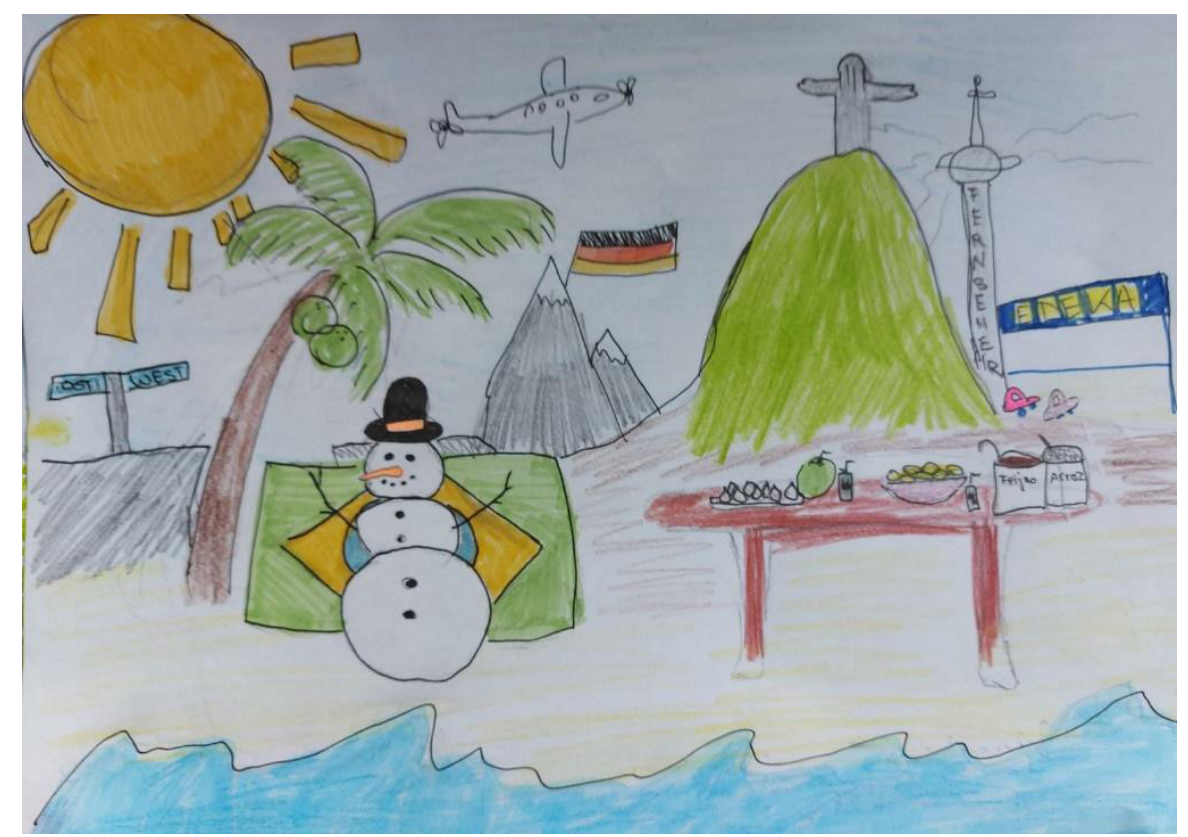

\#PraCegoVer: Desenho colorido. Numa praia, em primeiro plano ao centro, deitado na bandeira do Brasil um boneco de neve, à direita uma mesa cheia de comidas como coxinha, coco, feijão, arroz e latas de guaraná. À esquerda um coqueiro. Ao fundo uma estrada com placa indicativa leste, oeste. No canto superior esquerdo um enorme sol e seus raios, ao lado um avião. Também ao fundo, no centro duas montanhas, em uma delas a bandeira da Alemanha e na parte da praia, outra montanha com o Cristo Redentor, à direita uma torre de comando do aeroporto e dois carros.

O desenho 4, alinhado à percepção de uma identidade híbrida que já havia emergido da discussão sobre o desenho de Felícia, traz igualmente representações que remontam aos estereótipos (como a estátua do Cristo Redentor, um genuíno ícone, cartão postal de um

\footnotetext{
${ }^{15}$ Sobre as representações exóticas de brasilidade ver Simão e Marques (2020) que apresentam uma interessante abordagem com base em representações semelhantes contidas no filme Rio, de Carlos Saldanha.
} 
Rio de Janeiro) e a uma noção de brasilidade exótica (representada pelo coqueiro, a água de coco, a praia ensolarada) (SIMÃO; MARQUES, 2020). Pode-se considerar este tipo de representação exótica, pois, assim como a jaboticaba do desenho de Felícia, são referências distantes da realidade dessas crianças que crescem na Alemanha. Sobre a mesa podem ser vistas algumas representações culinárias do Brasil, algo como salgadinhos (coxinha, pão de queijo), arroz com feijão, e uma lata de guaraná. A perspectiva do desenho, que mescla em efeito de distanciamentos e proporções diferenciadas os dois universos do imaginário da autora (pelo fato de ser uma criança com background migratório brasileiro que cresce na sociedade alemã), mistura elementos das duas culturas (por exemplo, o boneco de neve e ao Cristo Redentor) e traz sinais de literacia nas duas línguas, o que remete à percepção que a criança tem de seu bilinguismo. Todos esses elementos associados podem ser interpretados como representação de um hibridismo cultural, evidenciado até mesmo na presença das duas bandeiras. Essa mistura é bem explicada na fala de Iara durante a discussão em grupo.

Como acima discutido, também o excerto 4 demonstra como a discussão é iniciada a partir das representações trazidas nos desenhos e como a dinâmica de co-construção vai se repetindo.

Excerto 4:

P: então Iara, pode falar, o que é que você desenhou aí, sobre o que é ser brasileirinho.

I: eu desenhei... um homem de neve na praia, que no Brasil tem praia, aqui na Alemanha também tem, mas não uma praia bonita. Aqui no Brasil onde, ... na maioria do Brasil não tem neve, então eu desenhei um homem de neve, porque na Alemanha tem neve. Aqui eu desenhei o sol, porque no Brasil tem muito sol. Aqui eu desenhei o Cristo redentor no Rio de Janeiro, porque é ... tipo... quando as pessoas aqui na Alemanha pensam no Brasil elas pensam no Rio de Janeiro, então eu desenhei o Rio de Janeiro. E aqui eu desenhei a comida brasileira, e bebida brasileira, porque eu gosto muito da comida brasileira e da bebida brasileira, porque eu gosto muito da comida brasileira, ela é muito gostosa, eu desenhei um, a bandeira do Brasil e da Alemanha, e desenhei também as coisas aqui que tem na Alemanha, tipo o Edeka, não tem no Brasil, e desenhei também o avião, porque pra chegar do Brasil pra Alemanha tem que ir com o avião e demora muito.

P: e o que é que isso tem a ver com ser brasileirinho aqui na Alemanha? por que é que quando eu te perguntei faça um desenho sobre o que é ser brasileirinho aqui na Alemanha você desenhou essas coisas?

I: é que são as coisas que representam o Brasil aqui na Alemanha, e as coisas que representam a Alemanha lá no Brasil. 
P: e como é que você sente isso de ser brasileirinho na Alemanha... eu estou vendo que você escreveu algumas coisas em alemão, algumas coisas em português...a bandeira da Alemanha tá lá longe, a bandeira do Brasil tá aqui na frente...

I: é que ... sei lá...

P: você fala português com quem?

I: com a minha família e com as minhas amigas brasileiras que falam português.

P: com as suas amigas do Brasil. Ou você fala português aqui na Alemanha também?

I: as vezes.

P: com quem?

I: com a minha mãe, com o meu irmão, com a minha cachorra, com os meus coelhos, com o meu pai. E com a minha amiga que tá aprendendo português.

P: quer dizer, então você fala muito português.

I: hum hum. (confirmou)

P: e o que é que você fala melhor, o alemão ou o português.

I: igualmente.

P: as duas línguas você fala bem?

I: hum hum.

P: e você também foi na Mala de Herança né?

I: sim.

P: e você gostava dos encontros?

I: mais ou menos.

P: do quê que você gostava?

I: de ver as outras pessoas que falavam português e de ver as minhas amigas.

A aproximação entre as imagens fornecidas pelo desenho e a interpretação subjetiva de Iara é evidente. É interessante perceber como ela mesma justifica a escolha das representações por serem, em sua perspectiva, "as coisas que representam o Brasil aqui na Alemanha, e as coisas que representam a Alemanha lá no Brasil." Ela se vale de referências culturais, paisagísticas, e da culinária para representar a brasilidade ou a identidade brasileira.

Nota-se que as representações de brasilidade produzidas servem de impulso para discussão, podendo ser usadas como meio de acesso a outros aspectos paralelos e de interesse central no estudo, como o modo como o aprendizado acontece, o estatuto que a LH tem para esses aprendentes, e a avaliação que fazem do modo como aprendem o PLH, no contexto não-formal. No caso de Iara, na mesma linha da percepção de Felícia, e como será visto, da percepção de Natan, as imagens possibilitaram que ela expressasse a sua percepção do bilinguismo como elemento constitutivo de sua identidade híbrida, o que fica evidenciado nos sinais de literacia nas duas línguas, que puderam ser tematizados 
durante a discussão do FG. Do mesmo modo, ainda que não tenham aparecido no desenho, as representações trazidas possibilitaram acessar as relações estabelecidas entre língua e identidade, bem como o estatuto atribuído ao PLH. Esta complementaridade dos métodos (com a intervenção da pesquisadora), permite um alargamento dos significados e inferir que, para ela, esta língua é também a língua da família, ou de um círculo restrito de amizades, o que reforça seu caráter de língua minoritária.

Semelhante interpretação pode ser feita do desenho 5, abaixo. Analisado juntamente com o excerto da discussão, traz a mesma linha argumentativa de Felícia e Iara nos desenhos 3 e 4, por trazer nítidas representações do hibridismo cultural (veja-se a combinação das duas bandeiras).

Desenho 5: Natan (12 anos).

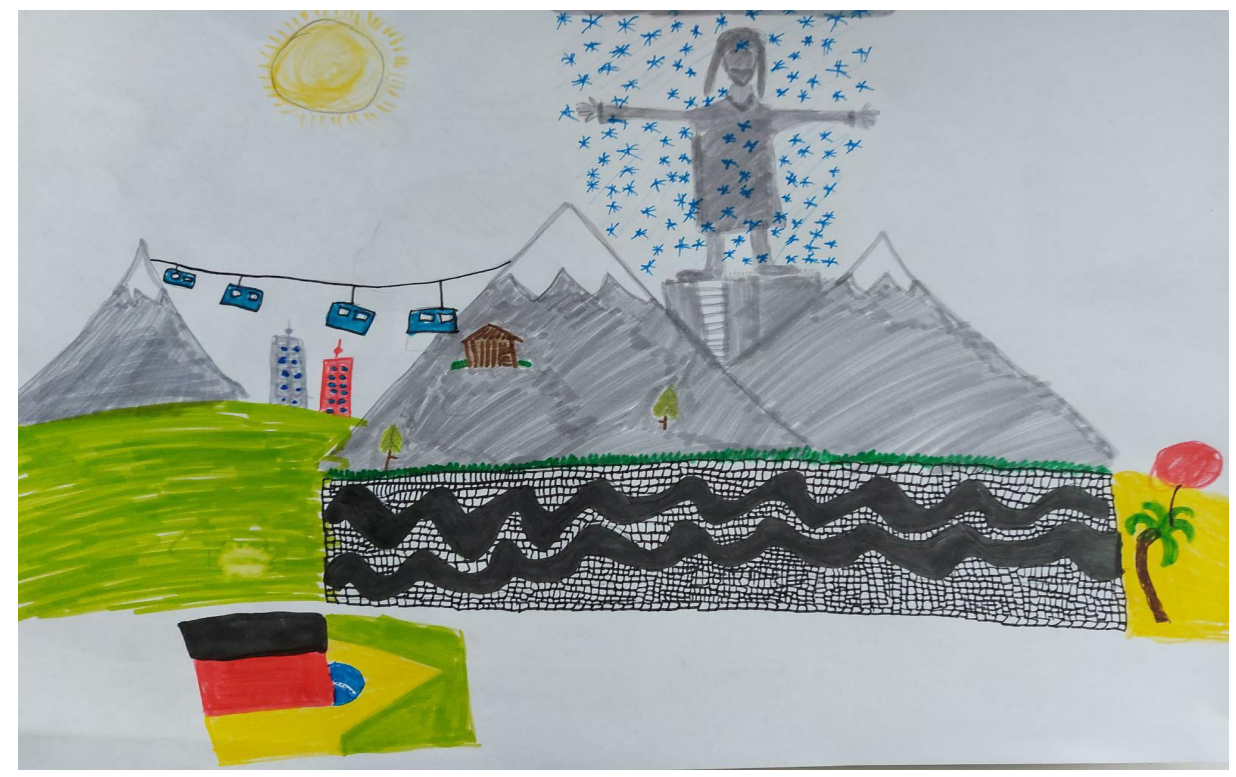

\#PraCegoVer: Desenho colorido. Ocupando a parte central, da esquerda para a direita, duas montanhas à frente, elas se unem a outra montanha ao fundo por um teleférico. Ao lado dessa montanha dois prédios e acima o sol com raios solares. Na frente das duas montanhas a calçada de Ipanema, num dos montes uma casa e algumas árvores e entre eles, o Cristo Redentor com muitos asteriscos em volta. No final da calçada, bem à direita um coqueiro na areia e uma bola. Abaixo, no centro esquerdo uma bandeira dividida ao meio, à esquerda a bandeira da Alemanha e à direita a do Brasil.

\section{Excerto 5:}

$\mathrm{N}$ : eu desenhei o Cristo, as montanhas, uma casinha na montanha, o que é típico aqui na Alemanha. Uma praia com uma bola, que tá voando por ali, aí eu desenhei montanhas, que é típico da Alemanha, neve por cima do Cristo, é porque aqui na Alemanha tem neve, sol, porque no Brasil 
tem sol, eu desenhei a Copacabana, porque tem no Brasil, e eu desenhei uma palmeira na praia, eu desenhei umas árvores na montanha, e isso é meio assim, uma mistura da Alemanha e do Brasil.

$\mathrm{J}$ : ah, e isso é ser brasileirinho aqui em Eichstätt pra você?

$\mathrm{N}$ : sim,

J: e por quê?

$\mathrm{N}$ : porque é meio assim uma mistura, as vezes tem neve, as vezes tem sol, não tem praia, mas tem montanha...

$\mathrm{J}$ : E essas duas bandeiras, o que é que isso quer dizer?

$\mathrm{N}$ : é uma mistura da Alemanha e do Brasil.

$\mathrm{J}$ : isso é ser brasileirinho em Eichstätt pra você?

$\mathrm{N}$ : é.

J: e você fala português com quem?

$\mathrm{N}$ : ah, eu falo com a minha mãe, com a minha irmã, eu falo as vezes português, né Iara, com o meu pai eu falo. Mas isso é não todas as vezes, também é mais quando eu brigo com ele, raramente que eu falo com ele em português, mas eu falo várias vezes, eu falo com a minha cachorra, com os coelhos, com os meus avós...

$\mathrm{J}$ : sim... e você gosta de falar português?

$\mathrm{N}$ : eu gosto. Gosto.

J: e você fala melhor português ou alemão? Como é que é? tem alguma coisa que é difícil no português pra você e que não é difícil no alemão? $\mathrm{N}$ : no português eu fico imitando o sotaque do meu pai, e aí agora as vezes eu fico assim, com o sotaque dele. Mas na verdade, o alemão é um pouco mais fácil pra mim, porque agora eu falo mais tempo que o português, mas português eu comecei a falar primeiro, aí é um pouco fácil também, mas o alemão é mais fácil.

$\mathrm{Na}$ análise da imagem juntamente com a fala de Natan percebe-se que as representações per se, como a explicação que faz sobre elas, se aproximam, permitindo chegar à mesma conclusão: sua identidade revela traços de hibridismo, de uma fusão de traços identitários diversos. Na continuidade da discussão em grupo, nota-se que o caminho para criar uma conexão com os temas já abordados, e chegar a uma opinião comum sobre o assunto, fica facilitado. Há um distanciamento das imagens, quando Natan, em sua fala, revela a visão que ele tem da língua alemã como a língua dominante, bem como sua visão sobre língua materna, mais precisamente, de sua vida com duas línguas maternas, ou suas percepções sobre o bilinguismo (equilibrado - ou não). Como nos outros casos acima analisados, este distanciamento permitiu um alargamento dos significados co-construídos.

As imagens de brasilidade representadas por Natan, como o Cristo Redentor, a ensolarada praia com o calçadão de Copacabana, a bola, (assim como a Amazônia desenhada por Felícia) são próximas de estereótipos sobre o Brasil (SIMÃO; MARQUES, 
2020), e podem talvez ser explicadas pelo fato de estas crianças conhecerem este país apenas nas férias, já que nasceram e crescem na Alemanha, e por estas serem também as imagens do Brasil mais propagadas na Alemanha.

O desenho 6, abaixo, traz também representações culinárias, como o guaraná e a feijoada que, tal como a bandeira nacional, são bastante frequentes. As festas típicas como a festa junina e o bumba-meu-boi, bem como a dança (representada pela menina vestida em trajes típicos coloridos), e as notas musicais remetem ao folclore brasileiro.

Desenho 6: Stefanie (14 anos).

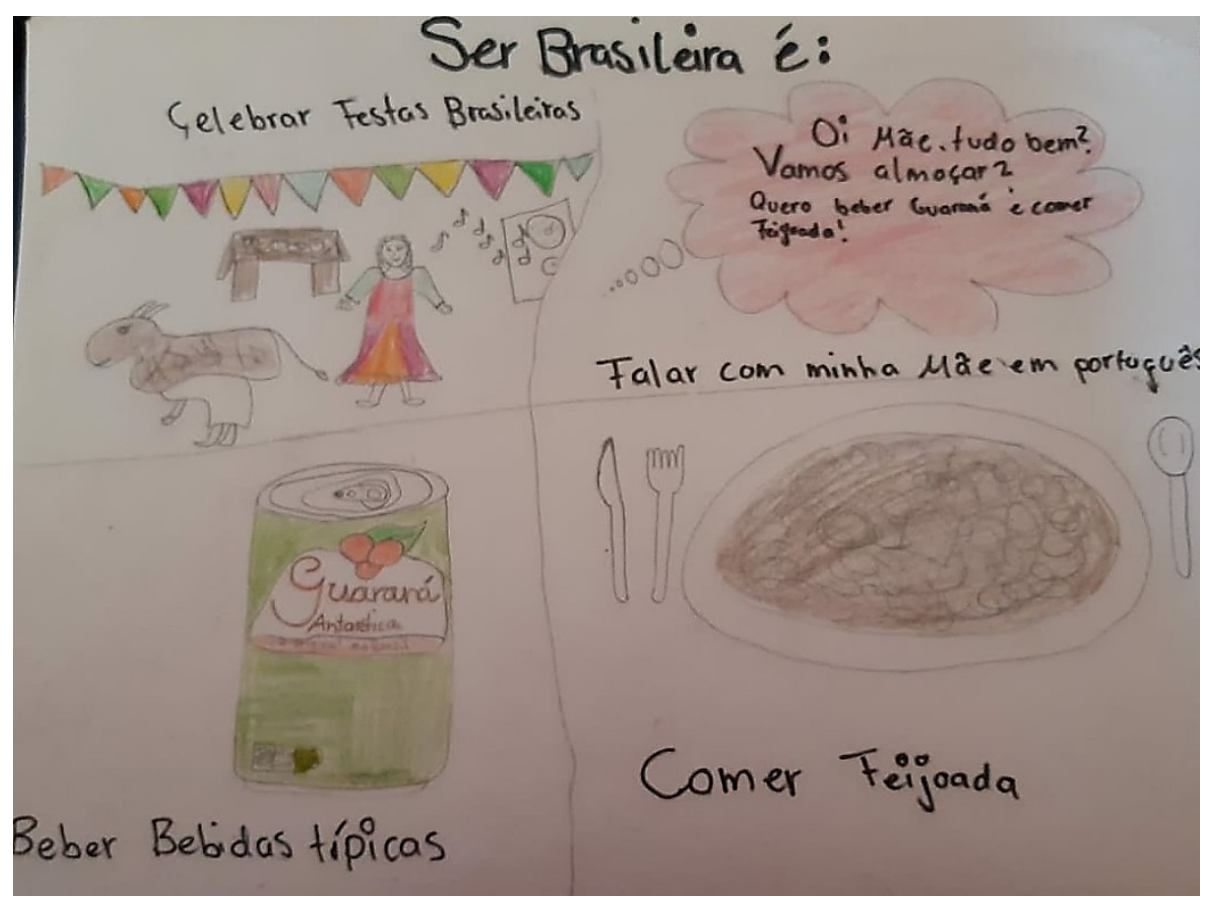

\#PraCegoVer: Desenho colorido dividido em quatro partes. Acima, centralizado o título Ser brasileira é. $1^{\mathrm{a}}$. parte lado esquerdo acima, a frase "celebrar festas brasileiras": bandeirinhas, notas musicais saindo de uma caixa de som, uma mulher com vestido longo vermelho, uma pessoa fantasiada de boi e ao fundo uma mesa decorada e vários alimentos. $2^{\mathrm{a}}$. parte, lado direito acima: um balão com a mensagem: Oi mãe, tudo bem? Vamos almoçar? Quero beber guaraná e comer feijoada? Abaixo a frase: falar com minha mãe em português. $3^{\text {a }}$. parte ao lado esquerdo, abaixo: uma lata de guaraná Antártica e a frase: "beber bebidas típicas". 4a . parte lado direito abaixo: direita um prato cheio de feijoada, os talheres em volta e a frase: "comer feijoada".

Da análise multimodal, constata-se a aproximação, pois as representações de Stefanie (imagem e fala) coincidem. No desenho de Stefanie, nota-se a riqueza de imagens contidas na narrativa visual. Neste caso, fica evidente como o desenho possibilita elencar várias categorias em uma única representação, revelando o potencial da narrativa visual, o que remonta à argumentação de Melo-Pfeifer e Ferreira (2017). 
O distanciamento é constatado em sua fala (Excerto 6). As representações de brasilidade por ela apresentadas permitiram trazer para a conversa outros aspectos que, espontaneamente, levaram a novas constatações, como, por exemplo, a questão do investimento para o aprendizado do PLH, e sua percepção do decréscimo da motivação com o aumento da idade.

\section{Excerto 6:}

S: então, o primeiro... aí onde está escrito, celebrar festas brasileiras, era pra ser o São João, essa festa aí, que claro, aqui tá pelo menos, festeja, fica festejando, e claro, me sinto como uma brasileira, que tem aqui na Alemanha as festas.

P: e o que mais que tem aí?

S: aqui a direita, eu botei, eu falando com a minha mãe em português, assim, essas frases que eu falo sempre, todo dia, ...

P: ahan... "oi mãe, tudo bem? quero comer feijoada" ser brasileira é falar português com a sua mãe.

S: é.

P: que interessante... você só fala português com ela?

S: eu só falo com ela, português, com meu papai eu também falo as vezes, mas só quando eu estou brigando com ele, perto de uns amigos meus que não entendem português.

P: muito bem.

e tem mais coisa aí, olha, beber bebidas típicas, comer feijoada.

S: a direita com a feijoada eu fiz, porque a mamãe sempre faz feijoada, gostosa, então eu me sinto no Brasil, como na minha avó, comendo uma feijoada, com farinha e arroz.

P: ahan, e o guaraná?

S: isso é legal, porque dá pra comprar aqui também, e eu fico matando a saudade do Brasil quando bebo um guaraná aqui em casa.

P: muito bem. Stefanie, você falou que usa o português com o seu pai, quando você não quer que algum amigo perceba que você está brigando com ele.

S: é.

P: então o português pra você é como uma língua secreta também.

S: é.

P: te serve para guardar uns segredos aí, né, aquilo que os outros não podem saber você fala em português. E você gosta de falar em português?

S: eu amo. Eu só falo em português, a maioria do tempo.

P: sim? você gosta mais de falar português ou de falar alemão?

S: português.

P: por quê?

S: porque alemão eu escuto aqui todo tempo na rua, cada metro tem uma pessoa falando alemão, aqui as pessoas que falam português não é 
tudo de uma vez, é só algumas pessoas que moram ao redor. Aí é legal, falar em português.

P: e pra você é difícil? falar português.

S: não, é muito fácil. É a minha primeira língua que eu falei.

$\mathrm{P}$ : e você gostava dos encontros da Mala?

S: não.

P: por quê?

S: porque eu sempre era a mais velha nesses encontros. Claro, tinha sempre alguma coisa que me interessava, mas no total, pra mim não era tão assim, pra minha idade, assim, que eu gosto.

P: mas quando você era pequena você gostava né?

S: claro, claro, isso é outra coisa.

P: porque é que você ia na mala, Stefanie?

S: por causa dos meus pais. Porque antes eles não queriam que eu ficasse aqui em casa sozinha, e aí ficaram me levando, e aí claro que eu fui.

Como nos outros desenhos analisados, a relação que tem com as línguas de seu repertório bilíngue é abordada, e reforçada como uma relação positiva. Os estatutos atribuídos ao PLH, bem como no caso do desenho 5, feito por Natan, aparecem de forma bem ordenada, percebidos como língua materna ou LH, que convive com a língua dominante da sociedade. Os sinais de literacia em língua portuguesa, do mesmo modo, dentro de uma perspectiva da multimodalidade, possibilitaram expandir a discussão para o aspecto do uso da língua, permitindo também captar imagens que só emergiram no material verbal. Pode-se, desta feita, reafirmar o potencial dos dois métodos de coleta e análise, quando usados de forma associada.

Tanto nas imagens produzidas nos desenhos quanto em sua fala, poucas informações novas foram acrescentadas à discussão em grupo, que apenas reafirmou a percepção comum do PLH como family language (CUMMINS, 2014), o que ficou evidenciado na visão de quase todos os participantes. É interessante perceber, mais uma vez, como dentre as representações de brasilidade acedidas (graças ao desenho), se destacam a culinária como importante elemento sensorial demarcador da identidade, ou paisagísticas, como a praia.

\section{DISCUSSÃO E CONCLUSÃO}

Com base em narrativas visuais de crianças bilíngues (alemão-português), este estudo buscou, em primeiro plano, conhecer as representações de brasilidade, a fim de articulá-las com o aprendizado do PLH em contexto não-formal de aprendizado na Alemanha. Em segundo plano, pretendia-se avaliar quais as vantagens dos 
métodos escolhidos e em que medida as técnicas usadas para a coleta e análise dos dados se complementam.

Quanto às imagens de brasilidade aqui apresentadas, e, portanto, endereçando a primeira questão de investigação proposta, constata-se que os aprendentes de PLH, no contexto aqui examinado, trazem imagens muito positivas, que denotam uma boa relação das crianças com seu repertório linguístico e sua complexa identidade bilíngue intercultural. As imagens permitem inferir que, embutido na transmissão da língua, a MH potencializa a transmissão de um conteúdo cultural, reafirmando a LH como língua-cultura, como anunciado na introdução. A MH é vista como um ambiente de identificação cultural para essas crianças, o que emerge do discurso, salientado na possibilidade de encontrar a comunidade próxima de amigos. O discurso das crianças evidencia, igualmente, a relevância das interações sociais em português com a família, comprovando a eficácia da proposta do projeto, e ressaltando o protagonismo materno na transmissão da LH.

Ao mesmo tempo, as representações obtidas da língua e da cultura remetem a uma visão de brasilidade bem próxima de um ideário da cultura popular (evidenciado nas repetidas referências a elementos da culinária, folclore, e paisagens como a praia), em certa medida exótica e estereotipada do Brasil (sugerido pela flora retratada). Isto talvez se explique, como adiantámos, pelo fato de estas crianças crescerem em um contexto linguístico-cultural dominante muito distante da realidade representada, e, provavelmente, conhecerem a cultura brasileira apenas de um contexto de férias.

As representações trazidas permitem inferir que, no contexto e junto do público analisados, a visão da língua e cultura é construída a partir do contato com a família (a próxima e a distante) e por meio dos conteúdos adquiridos também no âmbito do projeto MH que avaliam como relevante para o desenvolvimento do PLH. Além das imagens retratadas, constatou-se que o PLH tem, para essas crianças, um estatuto de língua da família (a próxima e a distante, no país de origem), como evidenciou o discurso comum resultante das discussões em grupo.

As imagens de brasilidade coletadas permitem constatar que a língua, além de outros elementos sensoriais e semióticos (como a culinária e o folclore, ou a literatura e a música), é um elemento de construção da identidade cultural, mais especificamente, de uma identidade etnolinguística, reforçada na articulação que fazem entre background migratório, uso das línguas e conexão com a família remanescente no Brasil.

Endereçando a segunda questão, sobre a relação das metodologias entre si, buscou-se demonstrar como as duas técnicas - o desenho e o FG - se completam: há representações que não aparecem nos desenhos, mas que são impulsionadas por eles, 
e emergem a partir da discussão em torno das imagens produzidas nos desenhos. Este é um aspecto relevante, pois a interpretação do investigador sobre as narrativas visuais (como também das narrativas escritas ou orais) é potencialmente subjetiva e, ao ouvir o autor das imagens, pode aproximar-se das intenções declaradas (que podem ser diferentes das intenções de produção). Em quase todos os desenhos estão presentes traços de (bi)literacia em maior ou menor quantidade, o que mostra que as crianças veem na multimodalidade um recurso para a transmissão e construção de significado com base na combinação dos seus repertórios.

No caso em tela, por exemplo, a figura materna, que não aparece nos desenhos, é destacada com frequência no discurso das crianças. Isso reforça o entendimento de que a narrativa visual pode ser complementada por uma metodologia que dê voz à eventual intenção do autor da imagem. Cabe pontuar que, no presente estudo, a análise do recurso a desenho e apresentação oral, de maneira associada, se reduziu a apenas 20 desenhos. Nos casos de uma quantidade muito grande de desenhos recolhidos, a análise quantitativa pode, todavia, ser suficiente, dependendo das questões investigativas.

No presente estudo, conclui-se que, graças à multimodalidade, os desenhos, analisados conjuntamente com o discurso, permitem inferir sobre o papel da família, especialmente da figura materna, que aparece como crucial na transmissão intergeracional do PLH, sendo também forte componente da dimensão emocional envolvida no processo de aprendizagem: o aprendizado é iniciado no ambiente familiar, por ele desenvolvido e mantido, com o objetivo de poder cultivar (ou retroalimentar) as relações familiares.

Como vimos, a união das duas metodologias - o uso das narrativas visuais, associado à análise de conteúdo das discussões geradas no FG - pode ser vista como conveniente casamento metodológico adequado à pesquisa com crianças e adolescentes plurilíngues, especialmente por ser uma abordagem pouco invasiva. Ademais, como ficou demonstrado, as duas metodologias se complementam de maneira a otimizar a interpretação dos resultados, já que estimulam a emergência de representações de formas diferentes. As representações de brasilidades recolhidas neste estudo, mais do que apenas uma imagem, permitiram responder questões investigativas mais específicas, revelando o potencial heurístico das duas metodologias associadas. 


\section{REFERÊNCIAS}

AHN, S. Using Multimodal Analysis to Explore Language Learner Identity Construction. In: KALAJA, P.; MELO-PFEIFER, S., Visualising Multilingual Lives: More than Words. Bristol: Multilingual Matters, 2019. p. 134-150.

BAGNOLI, A. Beyond the standard interview: The use of graphic elicitation and artbased methods. Qualitativ Research 9(5), 2009. p. 547-570.

BARONO, T. \& EISNER, E. Arts based research. Los Angeles: Sage. 2012.

BERGER, A. Media Research Techniques. Newburry Park, CA: Sage Publications, 1995.

BOKHORST-HENG, W.; MARSHALL, K. Informing research (practices) through pedagogical theory: focus groups with adolescents. International Journal of Research and Method in Education, 2019. p.148-162.

BOURDIEU, P. Outlines for a Theory of Practice. Cambridge: Cambridge University Press. 1977.

BYRAM, M.; MORGAN, C. Teaching-and-Learning. Language and Culture. Clevedon: Multilingual Matters, 1993.

CAStellotTi, V. ; COSTE, D. ; MOORE, D. Le proche et le lointain dans les représentations des langues et de leur apprentissage. In D. Moore (Coord.), Les représentations des langues et de leur apprentissage. Références, modèles, données et méthodes (pp. 101-131). Paris : Didier. 2001.

CASTELlOTTI, V. ; MOORE, D. Social representations of languages and teaching. Guide for the Development of Language Education Policies in Europe From Linguistic Diversity to Plurilingual Education. In: Reference Study for the Council of Europe. Strasbourg: Council of Europe, 2002.

COSTA LIMA, L. Implicações Da Brasilidade. In: Floema Especial - Ano II, n. 2 B, p. 13-22, out. 2006. ISSN 2177-3629 (versão eletrônica) Disponível em: https://periodicos2. uesb.br/index.php/floema/article/view/1648. Acesso em: 08.02.2021

COSTA WÄTZOLD, J. O papel da transmissão informal no aprendizado de POLH. In: Maria Luisa Ortiz Alvarez / Ana Luiza Souza (ed.): Português como língua de herança, uma disciplina que se estabelece. Campinas: Pontes, 2020. p. 95-110. 
COSTA WÄTZOLD; J. MELO-PFEIFER, S. Imagens da Língua Portuguesa e da Brasilidade em contextos de transmissão não-formal da Língua de Herança: o caso do dispositivo didático "Mala de Herança" em Munique. In: DEGACHE, C. \& HIRAKAWA, D. A. (Ed.) Atas do Congresso Internacional DIPROling, 3, 4 e 5 de outubro de 2018. Distância/proximidade e representações sobre a aprendizagem das línguas: facilidades, obstáculos, motivação e intercompreensão. Faculdade de Letras da Universidade Federal de Minas Gerais - Belo Horizonte, 2019. Disponível em: file://C:/Users/costa/ Downloads/1036-3900-1-PB\%20(4).pdf. Acesso em: 08.02.2021.

CUMMINS, J. Mainstreaming plurilingualism: Restructuring heritage language provision in schools. In: TRIFONAS, J.; ARAVOSSITAS, T. Rethinking heritage language education. Cambridge: Cambridge University Press, 2014. p.1-10.

DE ANDRE, M. E. Etnografia da Prática Escolar (5a ed.). São Paulo: Papirus. 2016.

DAMATTA, R. O que faz o brasil, Brasil? 12ª ed. Rio de Janeiro: Editora Rocco, 2001.

FANECA, R. M.; ARAÚJO E SÁ, M.; MELO PFEIFER, S. Is there a place for heritage languages in the promotion of an intercultural and multilingual education in the Portuguese schools? Language and Intercultural Communication. 16(1), 2016. p.1-25.

FREYRE, G. Interpretação do Brasil. Rio de Janeiro: José Olympio. 1947.

GALISSON, R. De la langue à la culture par les mots. Paris: Clé International. 1991.

GREEN, J.; DIXON, C.; ZAHARLICK, A. A etnografia como uma lógica de investigação. Educação em Revista, 42, 2005. p.13-79. Disponível em http://educa.fcc.org.br/scielo. php?script=sci_arttext\&pid=S0102-469820050002. Acesso em: 09 de 04 de 2020.

GREIG, A.; TAYLOR, J.; MACKAY, T. Doing Research with Children: a practical guide (3 ed). Los Angeles, London: Sage, 2013.

GUARESCHI, P. A técnica dos Grupos Focais como pesquisa qualitativa. Porto Alegre: Pontifícia Universidade Católica, 1996.

HALL, S. Representation: cultural representations and signifying practices (2nd ed.). London: Sage Publications. 1997.

HALL, S. We need to talk about Englishness. New Statesman. 23 ag 2012. (entrevista concedida a Jonathan Derbyshire). Disponível em: https:/www.newstatesman.com/ politics/uk-politics/2012/08/stuart-hall-we-need-talk-about-englishness Acesso em: 27.01.2021 
HALL, S. A identidade cultural da pós-modernidade. São Paulo: DP\&A, 2006

HASSEN, M. D. Grupos Focais de intervenção no projeto sexualidade e reprodução. Horizontes Antropológicos, 17(ano 8), 2002. p.159-177.

HOLLANDA, S. Raizes do Brasil. 25. ed. Rio de Janeiro: José Olympio, 1993.

HOPPERSTAD, M. H. Studying meaning in children's drawings. Journal of Early Childhood Literacy, 10(4), 2010. p. 430-452.

IBRAHIM, N. Children's Multimodal Visual Narratives as Possible Sites of Identity Performance. In: KALAJA, P.; MELO-PFEIFER, S. Visualising multilingual lives: more than words. Bristol: Multilingual Matters, 2019. p. 33-52.

JEWITT, C. An introduction to multimodality. In: JEWITT, C. The Routledge Handbook of Multimodal Analysis. New York: Routledge, 2009. p. 14-27.

KALAJA, P., DUFVA, H. \& ALANEN, R. Experimenting with visual narratives. In: Narrative research in applied linguistics, pp. 105-131. 2013.

KALAJA, P.; MELO-PFEIFER, S. Visualising Multilingual Lives: More than Words. Bristol: Multilingual Matters, 2019.

KRAMSCH, C. (1998). Language and culture. Oxford: Oxford University Press.

KRESS, G. Multimodality. In: COPE, B.; KALANTZIS, M. Multiliteracies: Literacy Learning and the Design of Social Futures. New York: Routledge, 2000. p.182-202.

KRESS, G.; VAN LEEUWEN, T. Multimodal Discourse: The Modes and Media of Contemporary Communication. London: Edward Arnold, 2001.

MARTELETO, R.; MEDEIROS PIMENTA, R. Pierre Bourdieu e a produção social da cultura, do conhecimento e da informação. (01. ed.) Rio de Janeiro: Garamond, 2017.

MAYRING, P. Einführung in die qualitative Sozialforschung. Weinheim: Beltz, 2016.

MELO-PFEIFER, S. The role of the family in heritage language use and learning: impact on heritage language policies. International Journal of Bilingual Education and Bilingualism, 18(1), 2015. p. 26-44.

MELO-PFEIFER, S. Drawing the plurilingual self: how children portray their plurilingual resources. IRAL - International Review of Applied Linguistics in Language Teaching 55(1), 55(1), 2017. p. 41-60. 
MELO-PFEIFER, S. "Tornar-se professor de línguas estrangeiras: reconstrução de percursos linguísticos e profissionalizantes com recurso a narrativas visuais". Participação convidada na mesa redonda "Métodos visuais na formação de professores: potencialidades e desafios para a formação e a investigação", no XVIII CONAELL - Congresso Nacional de Estudos Linguísticos e Literários e II CIELT - Congresso Internacional de Educação, Linguagem e Territorialidade. UNEMAT, 18.12.2020, Mato Grosso, Brasil). 2020.

MELO-PFEIFER, S.; FERREIRA, T. Diz-me lá que tu desenhaste aqui! Das narrativas visuais a uma intertextualidade multimodal? In: MELO-PFEIFER, S. \& SIMÕES, A. R. (ed.). Plurilinguismo vivido, plurilinguismo desenhado. Estudos sobre a relação dos sujeitos com as línguas. Santarém: ESE. 2017. p. 129-153.

MELO-PFEIFER, S. ARAÚJO E SÁ, M.H. A dimensão afetiva na interação plurilíngue: Dinâmicas de negociação de imagens e estereótipos na interação romanófona em chat. In: Revista Portuguesa de Educação, 30(2), 2017. p. 111-131.

MELO-PFEIFER, S.; SCHMIDT, A. Integration as portrayed in Visual Narratives by Young Refugees in Germany. In: KALAJA, P.; MELO-PFEIFER, S., Visualising Multilingual Lives: More than Words Bristol: Multilingual Matters, 2019. p. 53-72.

MOLINIÉ, M. From the Migration Experience to its Visual Narration in International Mobility. In: KALAJA, P.; MELO-PFEIFER, S. Visualising Multilingual Lives: More than Words Bristol: Multilingual Matters, 2019. p. 73-94.

MORAN, P. R., \& LU, Z. Teaching culture: perspectives in practice. Boston: Heinle \& Heinle, 2001.

MORGAN, D. Focus Group as qualitative research. Newburry Park, CA: Sage Publications, 1988.

NORTON, B. Identity and Language Learning - Extending the Conversation. Ontario: Multilingual Matters, 2013.

PATTON, M. Qualitative research and evaluation methods. Newbury Park, CA: Sage Publications, 1990.

PAVLENKO, A. Multilingualism and Emotions. In: Creese, A. B. The Routledge Handbook of Multilingualism. New York: Routledge Handbooks, 2012. p. 454 - 469.

RIBEIRO, D. O povo brasileiro. São Paulo: Companhia de Bolso, 2006. 
RIBEIRO, M. S. « Por uma biografia das coisas: a vida social da marca Havaianas e a invenção da brasilidade », Etnográfica [Online], vol. 17 (2), 2013. p. 341-368. Online desde 20 junho 2013, consultado em 01 fevereiro 2021. Disponível em: https://journals. openedition.org/etnografica/3148. Acesso em: 08.02.2021.

SCHWARZ, R. Nacional por subtração. In: SCHWARZ, R. Que horas são? Ensaios. São Paulo: Companhia das Letras, 1987.

SCHALLEY, A.; EISENCHLAS, S. (Eds.). Handbook of home language Maintenance and Development. Berlin: De Gruyter Mouton. 2020.

SIMÃO, D.; MARQUES, J. Cinema em aula de língua estrangeira: um estudo a partir das representações de brasilidade no filme Rio. In: Revista Humanidades e inovação: Educação formal e não formal, cultura e currículo III, v. 7 n. 8, 2020. p.403-414.

VAN LEEUWEN, T. Introducing Social Semiotics. London: Routledge. 2005.

VARGAS, E. V. O legado do discurso: brasilidade e hispanidade no pensamento social Brasileiro e Latino-Americano. Brasília: FUDAG, 2007.

WENGER, E. Communities of Practice and Social Learning Systems: the Career of a Concept. In: BLACKMORE, C. Social Learning Systems and Communities of Practice, London: Springer, 2010. p. 179-198. 


\section{ANEXOS}

Quadro 1: Focus Group - perguntas da entrevista $F G$ com as crianças.

\begin{tabular}{|c|c|}
\hline Pergunta de pesquisa a ser respondida & Perguntas colocadas nos 3 grupos focais \\
\hline $\begin{array}{c}\text { Que representações de brasilidade emergem } \\
\text { dos desenhos e das entrevistas de crianças } \\
\text { bilíngues na Alemanha? }\end{array}$ & $\begin{array}{c}\text { Como é que você aprende português? (FG1) } \\
\text { O que vocês fazem aqui nos encontros da } \\
\text { MH? } \\
\text { O que é a Mala de herança? (FG2) } \\
\text { Você gosta de vir aos encontros da MH? Por } \\
\text { que você vem? } \\
\text { O que você mais gosta aqui nos encontros da } \\
\text { MH? } \\
\text { Com quem você costuma falar português? } \\
\text { Em casa, você lê os livros com quem? } \\
\text { Você acha difícil falar português? } \\
\text { Por que é importante saber português pra } \\
\quad \text { você? } \\
\text { O que você acha de falar português e } \\
\text { alemão? } \\
\text { O que é ser brasileirinho em Munique para } \\
\text { você? (FG3) }\end{array}$ \\
\hline
\end{tabular}

Fonte: Elaborado pela autora. 
Quadro 2: Lista das crianças que participaram dos respectivos FGs e faixa etária.

\begin{tabular}{|c|c|c|}
\hline & Nome & Idade \\
\hline \multirow{9}{*}{$\begin{array}{c}\text { FG1 } \\
\text { (maio/2018, } 9 \text { participantes) }\end{array}$} & Nils & 4 anos \\
\hline & Mayra & 4 anos \\
\hline & Nicole & 6 anos \\
\hline & Celina & 8 anos \\
\hline & Carla & 9 anos \\
\hline & Lina & 10 anos \\
\hline & Natan & 10 anos \\
\hline & Iara & 10 anos \\
\hline & Felix & 11 anos \\
\hline \multirow{5}{*}{$\begin{array}{c}\text { FG2 } \\
\text { (fevereiro/2019, } 5 \\
\text { participantes) }\end{array}$} & Felicia & 8 anos \\
\hline & Kristina & 8 anos \\
\hline & Jimena & 9 anos \\
\hline & Mariana & 9 anos \\
\hline & Stefanie & 13 anos \\
\hline \multirow{8}{*}{$\begin{array}{c}\text { FG3 } \\
\text { (maio/2020, } 8 \text { participantes) }\end{array}$} & Nicole & 8 anos \\
\hline & Kristina & 9 anos \\
\hline & Felicia & 9 anos \\
\hline & Jimena & 10 anos \\
\hline & Mariana & 11 anos \\
\hline & Natan & 12 anos \\
\hline & Iara & 12 anos \\
\hline & Stefanie & 14 anos \\
\hline
\end{tabular}

Fonte: Elaborado pela autora. 
Quadro 3: Categorias de representações de brasilidad

\begin{tabular}{|c|c|c|c|}
\hline Categorias & Subcategorias & $\begin{array}{c}\text { Exemplos } \\
\text { nos desenhos } \\
\text { (frequência) }\end{array}$ & $\begin{array}{l}\text { Exemplos no discurso } \\
\text { (discussões FG) }\end{array}$ \\
\hline $\begin{array}{l}\text { Representações } \\
\text { linguísticas da } \\
\text { brasilidade: } \\
\text { imagens que } \\
\text { explicam o conceito } \\
\text { de brasilidade a } \\
\text { partir do uso da } \\
\text { língua e de suas } \\
\text { características }\end{array}$ & $\begin{array}{l}\text { (sócio) } \\
\text { linguístico/ } \\
\text { comunicativas }\end{array}$ & & $\begin{array}{c}\text { "falar português do Brasil, } \\
\text { porque como eu já disse, } \\
\text { na escola eu aprendo o } \\
\text { português de Portugal." }\end{array}$ \\
\hline & $\begin{array}{l}\text { símbolos } \\
\text { nacionais }\end{array}$ & $\begin{array}{l}\text { a bandeira do Brasil } \\
\text { (4), as cores da } \\
\text { bandeira }\end{array}$ & $\begin{array}{c}\text { "aqui eu desenhei a } \\
\text { bandeira, só para o Brasil, } \\
\text { porque (risos) a gente aqui } \\
\text { é todo brasileiro." }\end{array}$ \\
\hline & estereótipos & $\begin{array}{l} \\
\\
\text { futebol (1), praia (3), } \\
\text { Cristo redentor (2), } \\
\text { cocar do índio (1), } \\
\text { floresta amazônica } \\
\text { (1), Copacabana (2) }\end{array}$ & $\begin{array}{l}\text { “eu desenhei o Cristo, as } \\
\text { montanhas, uma casinha } \\
\text { na montanha, o que é } \\
\text { típico aqui na Alemanha. } \\
\text { Uma praia com uma bola, } \\
\text { que tá voando por ali, aí } \\
\text { eu desenhei montanhas, } \\
\text { que é típico da Alemanha, } \\
\text { neve por cima do Cristo, é } \\
\text { porque aqui na Alemanha } \\
\text { tem neve, sol, porque no } \\
\text { Brasil tem sol, eu desenhei } \\
\text { a Copacabana, porque tem } \\
\text { no Brasil, e eu desenhei } \\
\text { uma palmeira na praia, eu } \\
\text { desenhei umas árvores na } \\
\text { montanha, e isso é meio } \\
\text { assim, uma mistura da } \\
\text { Alemanha e do Brasil.” }\end{array}$ \\
\hline
\end{tabular}




\begin{tabular}{|c|c|c|c|}
\hline \multirow{5}{*}{$\begin{array}{l}\text { Representações } \\
\text { culturais de } \\
\text { brasilidade: } \\
\text { imagens variadas } \\
\text { que consubstanciam } \\
\text { o conceito de } \\
\text { brasilidade }\end{array}$} & literatura & & $\begin{array}{c}\text { “eu também estou lendo o } \\
\text { livro da Pilar, que também } \\
\text { é em português, quer dizer, } \\
\text { Diário da } \\
\text { Pilar, mas é um livro que } \\
\text { escreve lá, e eu também } \\
\text { leio muita revista da turma } \\
\text { da Mônica..." }\end{array}$ \\
\hline & futebol & $\begin{array}{c}\text { camisa do } \\
\text { flamengo (1) }\end{array}$ & $\begin{array}{l}\text { "e a blusa do flamengo, } \\
\text { que o vovô gosta muito do } \\
\text { flamengo, e ele mora no } \\
\text { Brasil. E eu também gosto } \\
\text { do flamengo. E o Nicolas } \\
\text { também tem a blusa do } \\
\text { flamengo." }\end{array}$ \\
\hline & $\begin{array}{c}\text { datas e } \\
\text { festividades }\end{array}$ & $\begin{array}{c}\text { festa junina (3), } \\
\text { bumba meu boi (1) }\end{array}$ & $\begin{array}{c}\text { "então, o primeiro... aí } \\
\text { onde está escrito, celebrar } \\
\text { festas brasileiras, era pra } \\
\text { ser o São Joao, e claro, me } \\
\text { sinto como uma brasileira, } \\
\text { que tem aqui na Alemanha } \\
\text { as festas." }\end{array}$ \\
\hline & culinária & $\begin{array}{c}\text { guaraná (2), arroz } \\
\text { com feijão (3), } \\
\text { água de coco } \\
\text { (2), brigadeiro, } \\
\text { jabuticaba (1), } \\
\text { pão de queijo (1), } \\
\text { coxinha (1), doce de } \\
\text { leite (1) }\end{array}$ & $\begin{array}{l}\text { "eu fico matando a saudade } \\
\text { do Brasil quando bebo um } \\
\text { guaraná aqui em casa." }\end{array}$ \\
\hline & étnicas & cocar de índio (1) & $\begin{array}{c}\text { "aqui eu desenhei, aquelas, } \\
\text { é... cocar, do índio, porque } \\
\text { a gente aprende muito } \\
\text { sobre os índios." }\end{array}$ \\
\hline
\end{tabular}




\begin{tabular}{|c|c|c|c|}
\hline & geografia & $\begin{array}{l}\text { Rio de Janeiro (2), } \\
\text { Brasil no globo } \\
\text { terrestre (1) calçadão } \\
\text { de Copacabana (2), } \\
\text { praia }\end{array}$ & $\begin{array}{c}\text { “aqui eu desenhei o } \\
\text { Cristo redentor no Rio de } \\
\text { janeiro, porque é ... tipo... } \\
\text { quando as pessoas aqui } \\
\text { na Alemanha pensam no } \\
\text { Brasil elas pensam no } \\
\text { Rio de Janeiro, então eu } \\
\text { desenhei o Rio de janeiro.” }\end{array}$ \\
\hline & história & & $\begin{array}{c}\text { “também falar sobre a } \\
\text { história do Brasil, assim, } \\
\text { sim que era mais ou menos } \\
\text { pros índios assim.” }\end{array}$ \\
\hline & lúdicas & jogo de futebol (1) & \\
\hline & folclore & $\begin{array}{c}\text { dança (1), bumba } \\
\text { meu boi (1), festa } \\
\text { junina (3) }\end{array}$ & $\begin{array}{l}\text { “que na Mala de herança } \\
\text { a gente canta muito, } \\
\text { canções, e também a gente } \\
\text { aprende palavras, e com a } \\
\text { leitura também, e a gente } \\
\text { também vem aqui, a gente } \\
\text { faz muitas atividades, e } \\
\text { aprende muitas coisas, } \\
\text { dança não pode faltar, e a } \\
\text { gente não fala alemão, a } \\
\text { gente fala português, é... } \\
\text { Brasil..." }\end{array}$ \\
\hline
\end{tabular}




\begin{tabular}{|c|c|c|c|}
\hline & musicais & & $\begin{array}{l}\text { “eu estou participando } \\
\text { do teatro do Vila Lobos, } \\
\text { aí eu acho que ele é um } \\
\text { compositor, eu acho que } \\
\text { português, ou brasileiro, } \\
\text { é... que compôs várias } \\
\text { músicas. Ciranda } \\
\text { Cirandinha, Fui ao tororó, } \\
\text { A canoa, e O cravo e a } \\
\text { Rosa. E também o teatro da } \\
\text { capivara, nós fizemos duas } \\
\text { vezes.” }\end{array}$ \\
\hline & fauna e flora & $\begin{array}{l}\text { jaboticaba (1), } \\
\text { floresta amazônica } \\
\text { (1), coqueiro (2), } \\
\text { capivara (1) }\end{array}$ & $\begin{array}{c}\text { "eu desenhei jaboticaba, } \\
\text { a Amazônia, a praia, a } \\
\text { bandeira do Brasil e eu na } \\
\text { casa da vovó." }\end{array}$ \\
\hline $\begin{array}{c}\text { Representações } \\
\text { socioafetivas da } \\
\text { brasilidade: } \\
\text { imagens que } \\
\text { abarcam a dimensão } \\
\text { emocional da língua } \\
\text { conectando-a com a } \\
\text { identidade cultural }\end{array}$ & família & avó (1) & $\begin{array}{c}\text { “e quando a mamãe lê um } \\
\text { livrinho em português, e } \\
\text { aí ela fala português com } \\
\text { a gente... e eu também } \\
\text { quando ela lê pra gente... e } \\
\text { quando a gente tá falando } \\
\text { com a vovó, que ela tá lá } \\
\text { no Brasil, aí também fala } \\
\text { português." }\end{array}$ \\
\hline
\end{tabular}

Fonte: Elaborado pela autora.

Recebido em: 17 out. 2020.

Aceito em: 10 fev. 2021. 